\title{
Climate Change Risk of Urban Growth and Land Use/Land Cover Conversion: An In-Depth Review of the Recent Research in Iran
}

\author{
Sorour Esfandeh ${ }^{1, *}$, Afshin Danehkar ${ }^{1, *}$, Abdolrassoul Salmanmahiny ${ }^{2}$, Seyed Mohammad Moein Sadeghi ${ }^{3}$ (D) \\ and Marina Viorela Marcu ${ }^{3}$ (D)
}

1 Department of Environmental Science and Engineering, Faculty of Natural Resources, University of Tehran, Karaj 31587-77878, Iran

2 Department of Environmental Sciences, Faculty of Fisheries and Environmental Sciences, Gorgan University of Agricultural Sciences and Natural Resources, Gorgan 49189-43464, Iran; mahini@gau.ac.ir or rassoulmahiny@gmail.com

3 Department of Forest Engineering, Forest Management Planning and Terrestrial Measurements, Faculty of Silviculture and Forest Engineering, Transilvania University of Brasov, 500123 Brasov, Romania; seyed.sadeghi@unitbv.ro or moeinsdgh@hotmail.com (S.M.M.S.); viorela.marcu@unitbv.ro (M.V.M.)

* Correspondence: sorour_esfandeh@ut.ac.ir (S.E.); danehkar@ut.ac.ir (A.D.)

Citation: Esfandeh, S.; Danehkar, A.; Salmanmahiny, A.; Sadeghi, S.M.M.; Marcu, M.V. Climate Change Risk of Urban Growth and Land Use/Land Cover Conversion: An In-Depth Review of the Recent Research in Iran. Sustainability 2022, 14, 338. https://doi.org/10.3390/su14010338

Academic Editor: Brian Deal

Received: 20 November 2021 Accepted: 24 December 2021 Published: 29 December 2021

Publisher's Note: MDPI stays neutral with regard to jurisdictional claims in published maps and institutional affiliations.

Copyright: (c) 2021 by the authors. Licensee MDPI, Basel, Switzerland. This article is an open access article distributed under the terms and conditions of the Creative Commons Attribution (CC BY) license (https:// creativecommons.org/licenses/by/ $4.0 /)$.

\begin{abstract}
This research is the first literature review of the past three decades' studies on the effects of urban development and land use/land cover (LULC) change on Iran's climate change. For this purpose, 67 articles were found, evaluated, and classified according to the spatial and temporal scale, case study, period, data type, climatic factor, methodology, and meteorological data. Moreover, the reviewed literature methodologies were classified according to the purpose, method, and data source. According to the spatial-scale results, national- and city-level studies had the lowest and highest numbers, respectively. Tehran was the most case studies because Tehran is Iran's capital and the largest metropolitan city. In terms of the temporal scale, studies predicting future changes (urban development and climate change) included $5 \%$ of the total literature. Satellite images were the most applied data in the reviewed literature (58\%). Overall, $79 \%$ of the studies used temperature-related factors to explain the climatic impacts of urban growth and LULC conversion. Spatial modeling with $52 \%$ publications was the most used method, while numerical modeling with $12 \%$ studies was the least used method. This review showed broad study gaps in applying numerical models, neighborhood scales, urban micro-scale parameters, and long-term projections forecasts due to rapid urban development in Iran compared to the rest of the world. Therefore, our synthesis will assist researchers in facilitating better design for future studies in Iran and similar countries.
\end{abstract}

Keywords: environmental sustainability; national synthesis; urban development; urban expansion; urbanization; Tehran

\section{Introduction}

One significant consequence of the increasing human population and urbanization tendency is the global-scale challenge of uncontrolled urban expansion. The world's urban population was about 30\% in 1950 and surpassed 50\% in 2014. It is also estimated to reach $60 \%$ by 2030 , accounting for five billion of the world's eight billion people [1]. Urban expansion influences local, regional, and global climate through two main mechanisms. First, changes in urban characteristics, such as increasing urban heat, affect the local temperature, atmospheric flows, and the intensity and frequency of lightning strikes. These changes alter the precipitation pattern toward torrential rains and storms during warm seasons and incur severe, costly damages. Moreover, temperature changes may reduce the urban environments' climate comfort and incur extra per capita expenditures due to increasing energy consumption (electricity and water) in warm months. Review studies 
show that urbanization reduces green space, increases impervious surfaces, and alters albedo compared to rural surfaces [2-4]. Second, changes in air pollutants' transport and dispersion affect the regional and global climate [5].

Increasing air pollutants' concentrations and their associated environmental, health, social, and economic consequences are among the most critical challenges facing many urban areas and their populations worldwide. A large body of research exists on the effects of urban physical expansion on urban climate and air quality in the literature. These studies have focused mainly on the characteristics of urban atmospheric turbulence in the planetary boundary layer (PBL), differences in meteorological variables between urban and rural areas (such as air temperature, wind speed, heat island, and precipitation), or observational study techniques [6-11]. With increasing technical accuracy since the late 2000s, most review articles have begun to explain the characteristics of micro-urban parameters derived from numerical climate models and climate prediction [12-19]. Studies were directed toward understanding the contribution of large urban areas to air pollution and dispersion and global warming, health impacts of air pollution, the impacts of small- and large-scale urban expansion on climate, and urban weather and climate modeling [5]. In other words, a scale shift can be noted from coarse to fine in the investigation of urban expansion and climate indicators. The focus of this research is on the micro-scale modeling of the effects of large urban areas on climatic elements, such as the spatio-temporal distribution of heat, dispersion of urban pollutants, urban airflow patterns, and deterioration of the urban heat balance due to the changing urban canopy, increasing or decreasing turbulent flows in the urban's atmospheric boundary layer that occur due to the urban surface heterogeneity and chemical transformation of pollutants during emission processes.

Despite the wealth of studies in this field, our knowledge is still inadequate in some critical parts of the world, such as Iran, which has faced unprecedented and, partly, uncontrolled urban expansion in recent decades. As a developing country, Iran has faced increasing population growth and urbanization. In 2016, the population of Iran was estimated to be 79 million, of which 59 million were urban residents. From 2011 to 2016, Iran's urban population increased by 5 million [20]. According to the World Bank, the Iran urbanization ratio increased from $26 \%$ in 1882 to $34 \%$ in 1961 and $770 \%$ in 2012 and has surpassed $73 \%$, which is about double the world average.

Population growth, rapid socio-economic development, and the subsequent growth of urban areas and land use/land cover (LULC) change in Iran have resulted in local and regional climate change, increasing weather anomalies and other related consequences, such as sudden rainfall, severe storms, drought, and urban mean temperature increase [21]. Many Iranian urban areas are struggling with increasing air pollutant and dust concentrations. These problems have reduced the urban environments' climatic comfort and led to the consumption of excessive energy, water, and other resources and other environmentaleconomic challenges.

The global importance of mitigating climate change and creating compatible, flexible, and resilient urban environments as one of the Sustainable Development Goals highlights the importance of understanding the causes and consequences of urban-growth-induced climate change. This importance is even more significant in Iran as a rapidly urbanizing arid and semiarid country [22]. Hence, this review aimed to collate information about the effect of urban expansion and LULC conversion on climate change in the reviewed literature to identify their strengths and weaknesses and shape future research direction. Specifically, this review addressed the following goals: (1) identify the trend in urban growth research and the effect of conversion of LULC on climate change in Iran compared to other countries, (2) identify more climatic factors and data in these articles, (3) investigate methodological features and spatial and temporal scales in these articles, and (4) identify the essential scientific gaps in these articles. The review content also included the methodology and article classification, result interpretation, discussion, recognition of gaps, and the overall conclusion. 


\section{Materials and Methods}

The main framework of this paper was to review articles published exclusively on the relationship of climate variability with urban growth and LULC conversion in Iran. To do this, important national (Magiran, Scientific Information Dataset (SID), Civilica) and international (Scopus, Web of Science, and Google Scholar) databases were evaluated from 1991 to 2020. The keywords used were "urban growth," "land use land cover," and "climate change." The reference list of the identified articles was also investigated to retrieve additional pertinent papers. We restricted the document type to "research articles," "conference papers," and "reviews" published in English and Persian languages. All studies derived from the national and international search engines $(n=103)$ were stored in a spreadsheet, and we were checked for whether they were the same as one another. Thirty-six papers were duplicated among databases, and therefore, they were excluded. In total, 67 articles published over the past three decades were selected and categorized in terms of spatial and temporal scales, case study, period, data type, climatic factors, methodology, and meteorological data, as displayed in Figure 1.

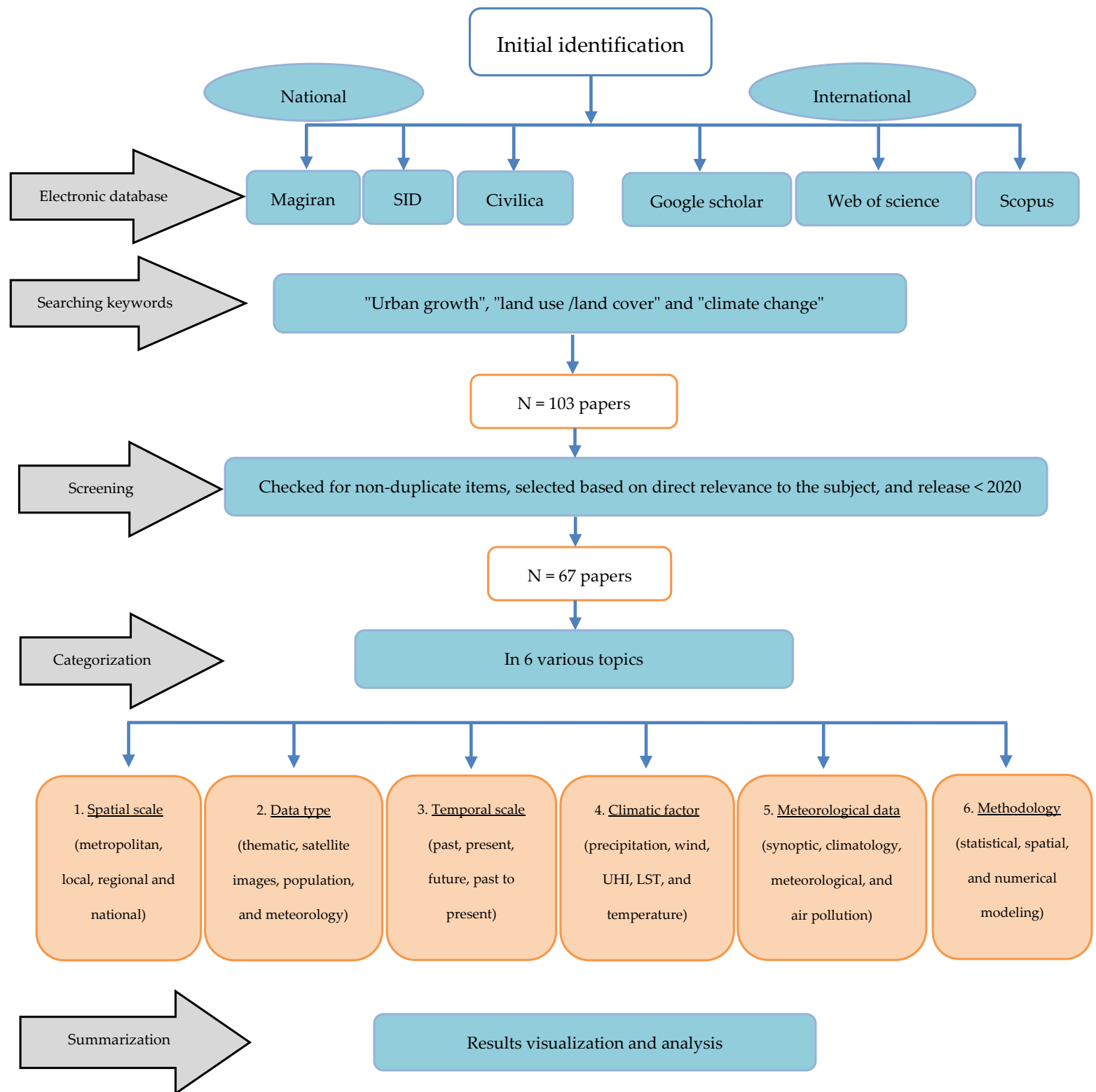

Figure 1. Flowchart of stages in the literature review process. 


\section{Results}

Table S1 (in the Supplementary Materials) shows the reviewed literature on the impact of urban development and land use change in Iran according to the spatial and temporal scales, case studies, period, data type, climatic factors, and methodology.

\subsection{Spatial Scale}

The studies' spatial scale included local (i.e., part or the entire extent of the city), metropolitan area (containing two or more adjacent urban regions or a metropolitan), regional, and national scales. Our results showed that most studies $(68 \%)$ were conducted at the local scale, followed by the metropolitan area scale with $28 \%$. However, regional- and national-scale studies were minimal, accounting for $3 \%$ and $1 \%$ of the studies, respectively. Case studies are shown in Figure 2, indicating a clear skew in selecting case studies.

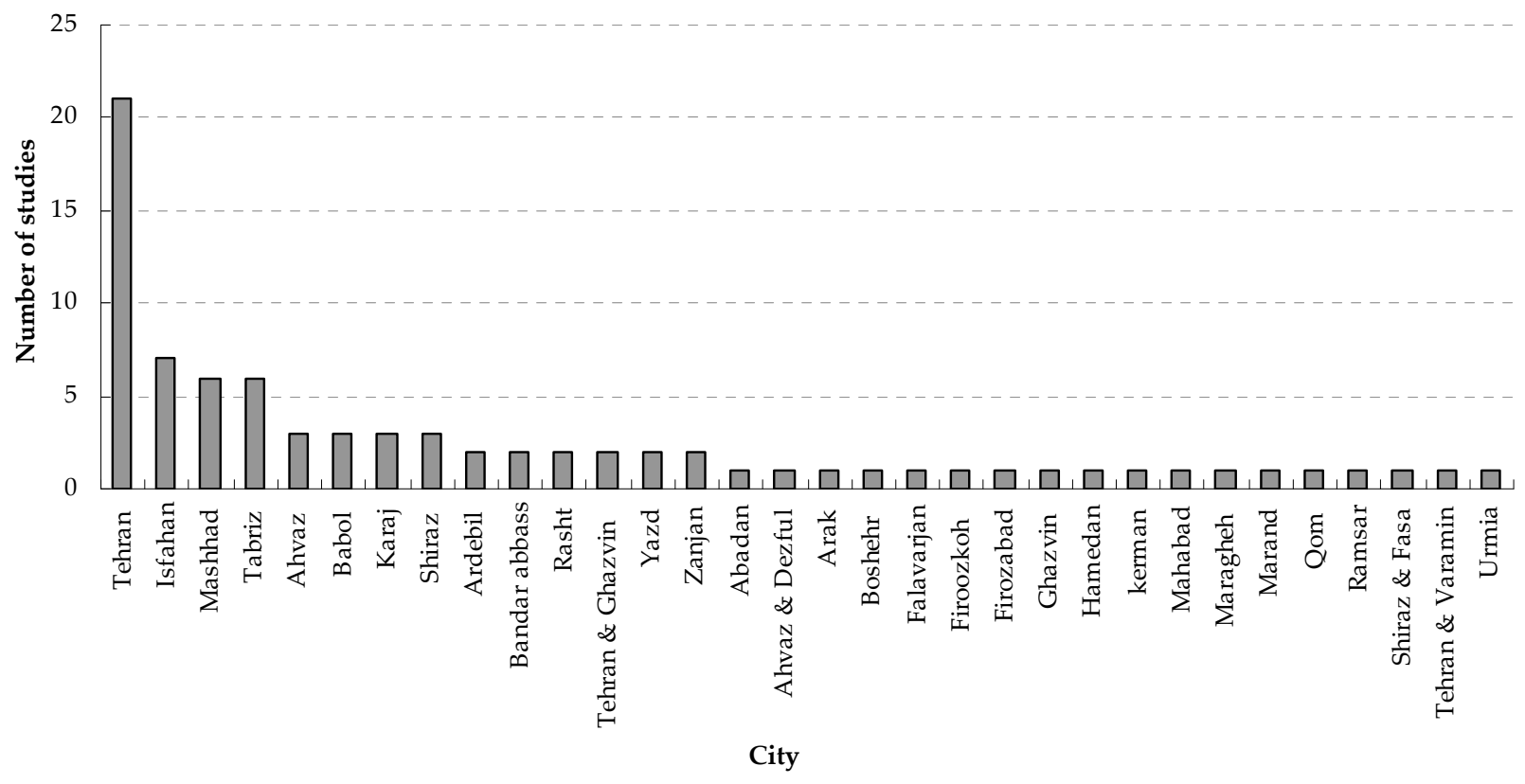

Figure 2. Number of case studies in the reviewed literature.

\subsection{Temporal Scale}

The articles were categorized into four temporal scales: past, present, past-to-present, and future. Past and present studies were published in the recent and distant past, respectively. Studies conducting a temporal analysis were classified as past-to-present. As shown in Figure 3, most of the articles fell into the past-to-present temporal scale and only $5 \%$ fell into the future temporal scale. Moreover, according to Table S1, periods in these studies were divided into five categories in which studies with only 1-year data were $32 \%, 2-10$-year data were $16 \%, 11-20$-year data were $12 \%, 21-30$-year data were $15 \%$, and long-term (>30 years) data were $23 \%$.

\subsection{Data Type}

The data used in the articles included meteorological data, satellite imagery, demographic data, thematic maps, and their combination. The percentage contribution of each data type in the selected studies is shown in Figure 3. Satellite imagery was the most common type of data (58\%; Figure 4). Forty percent of the studies used a combination of these data, including meteorological/demographic data, meteorologi$\mathrm{cal} /$ satellite data, demographic/satellite data, meteorological data/thematic maps, demographic data/thematic maps, meteorological, demographic data / thematic maps, meteorological/ satellites/demographic data, as well as all data types. 


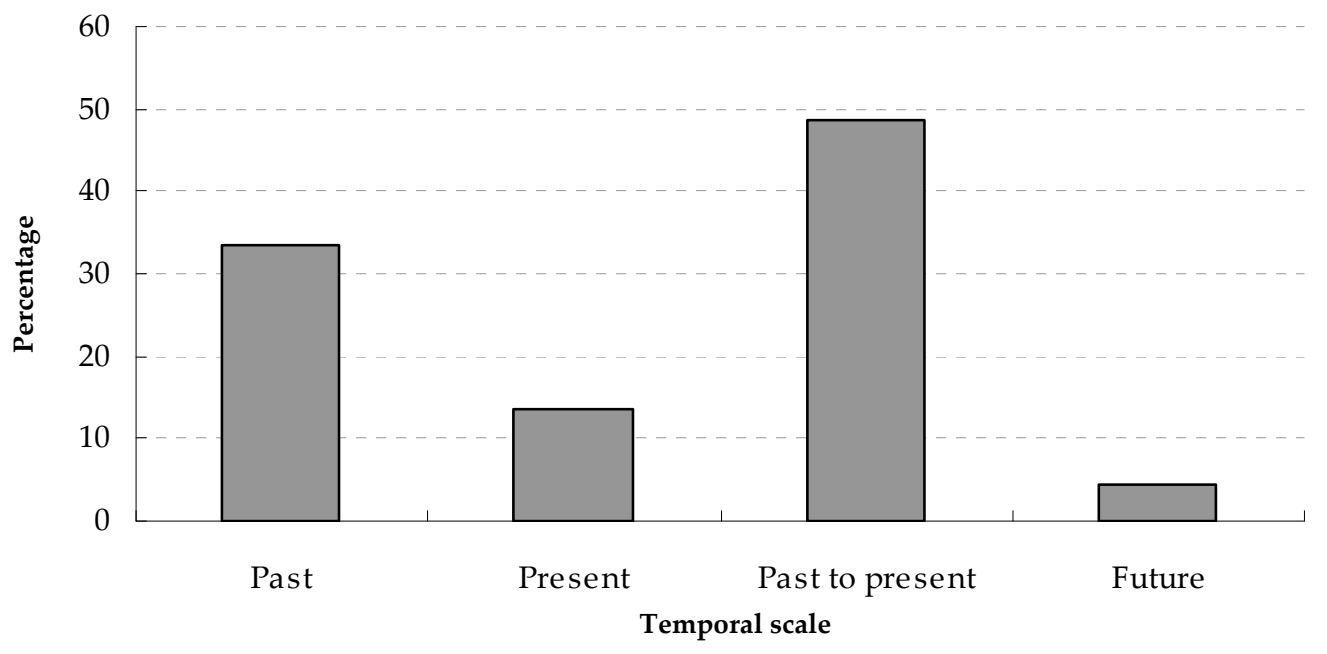

Figure 3. Temporal scale in the reviewed literature.

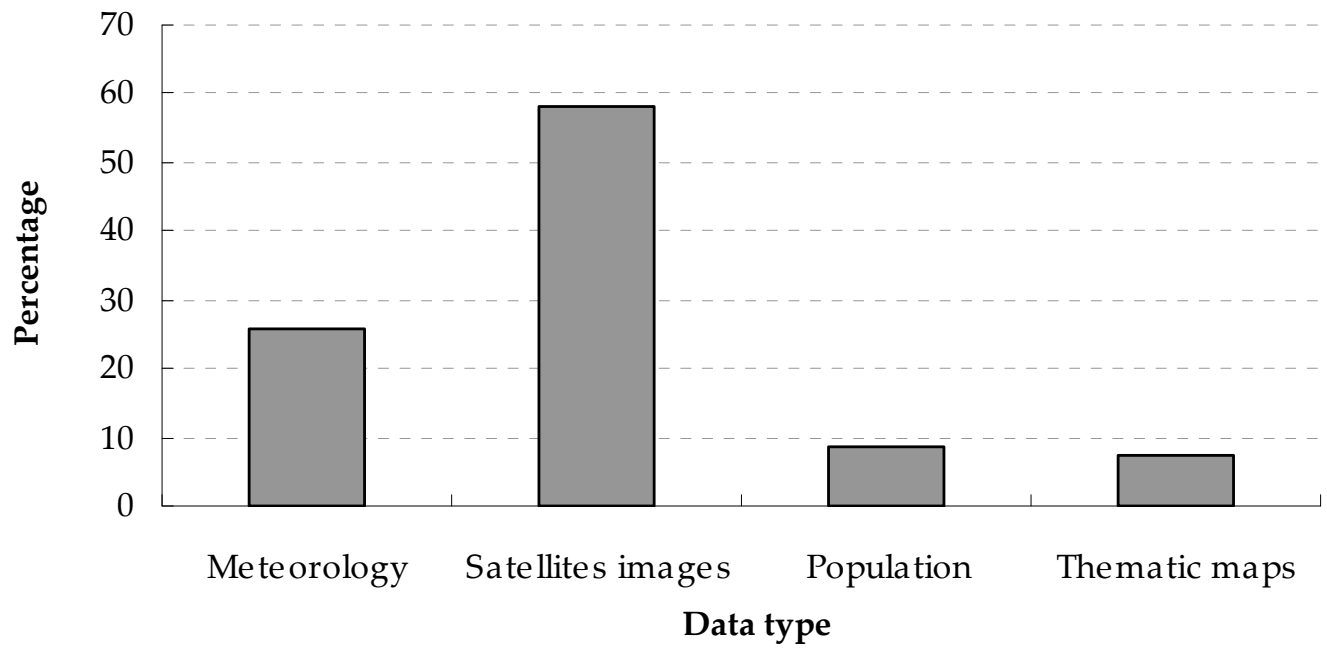

Figure 4. Data type in the reviewed literature.

\subsection{Climatic Factors}

Several climatic factors were found to be affected by urban expansion and LULC conversion, including air temperature (mean, maximum, and minimum values), wind direction and velocity, precipitation, LST, and UHIs. These and some other parameters were also combined to explore this association, such as temperature/wind, temperature/vegetation, temperature/air pollutants, temperature/relative humidity, surface temperature/heat island, temperature/cloudiness, temperature/precipitation, surface temperature/air pollutants/heat island, air pollutants/wind speed/surface temperature, temperature/precipitation/upward long-wave radiation, temperature/precipitation/relative humidity/cloudiness/wind, and surface temperature/surface long-wave flux/total ozone/ precipitation/carbon density. Figure 5 shows the percentage contribution of each climatic factor in the reviewed literature. Overall, $79 \%$ of the studies used temperature-related factors to explain urban growth and LULC conversion (Figure 5).

\subsection{Methodology}

The selected studies' methodology was broadly categorized into three modeling classes: spatial, statistical, and numerical. The percentage use of each methodology used in the selected studies is shown in Figure 6, indicating that spatial modeling of urban growth and LULC conversion was the most common methodology applied in $52 \%$ of the studies. 


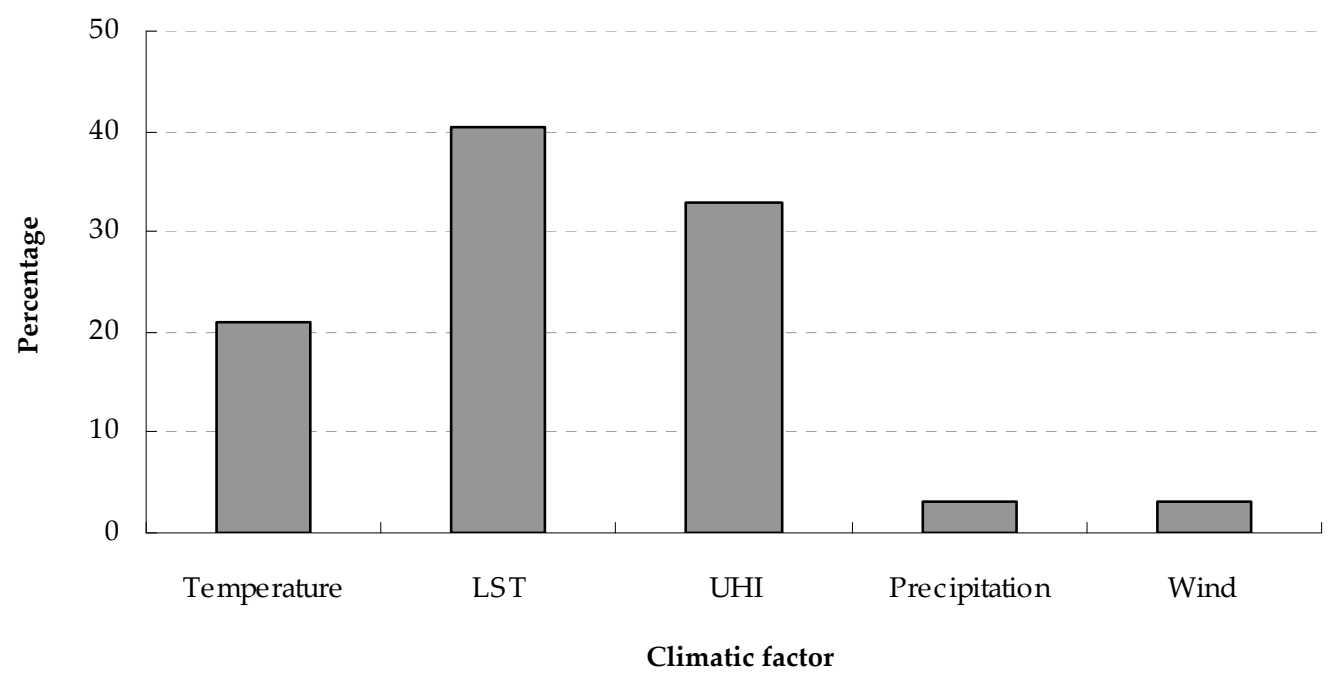

Figure 5. Climatic factor in the reviewed literature.

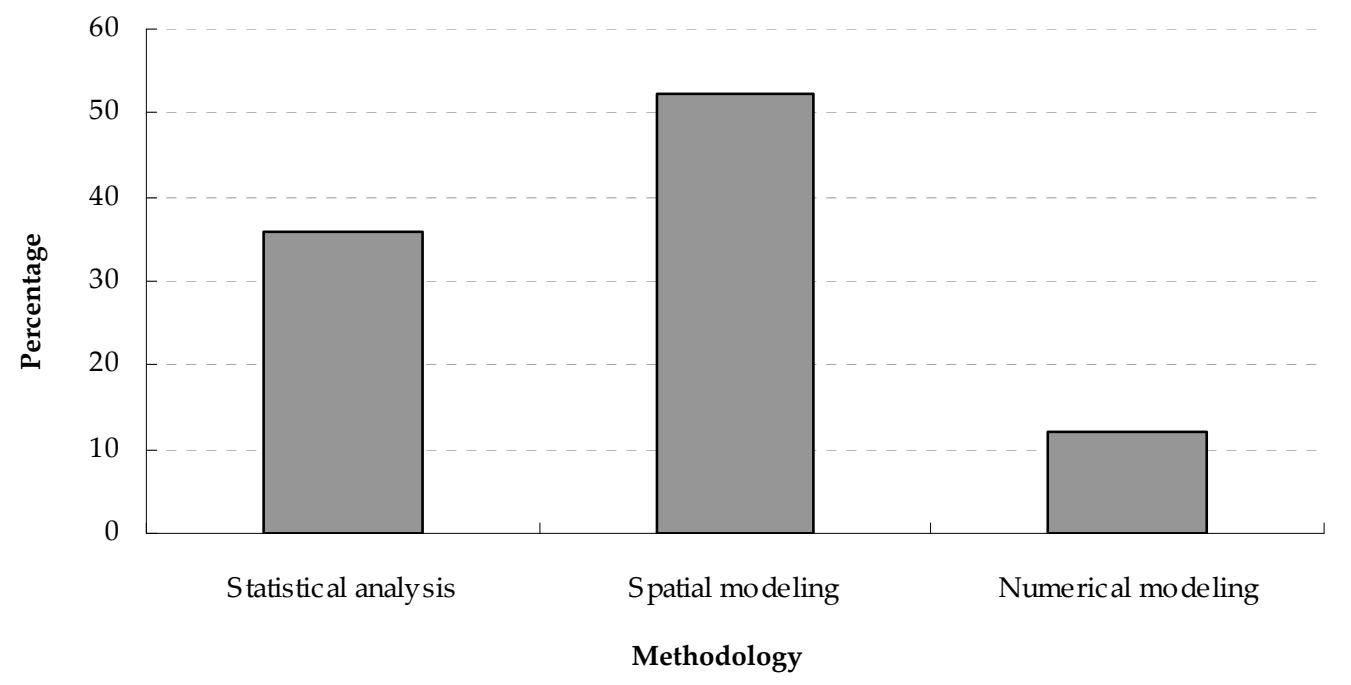

Figure 6. The methodology of the reviewed literature.

\subsubsection{Spatial Modeling}

Spatial models are a methodology or set of analytical techniques used to explore the spatial relationship between geographic attributes. This methodology mainly includes image classification and production of LULCs or urban areas in different periods and their comparison, retrieval of LST or heat islands as climatic factors, and evaluation of the relationship of spatial changes or the intensity of heat islands, LST, and other climatic factors with different LULCs. Of note is that this investigation included a visual comparison of spatial layers and their quantitative evaluation, analysis, and statistical comparison.

A well-known example of climate change in urban development is UHI, referring to the higher temperature of urban areas than their surroundings [23]. UHIs affect the temperature comfort of the urban environment and increase energy consumption by airconditioning systems and, therefore, reduce the air quality of urban areas compared to their surroundings. Hence, urban-growth-driven changes in climatic parameters also increase energy consumption that act as a significant source of heat emission into the atmosphere. The relationship between UHIs and energy consumption in densely populated cities, such as Washington, Los Angeles, and Dallas, showed that for an average temperature increase of 2 to $3^{\circ} \mathrm{F}\left(1\right.$ to $\left.1.5^{\circ} \mathrm{C}\right)$, there would be an increase of 1.5 to $2 \%$ in the maximum load of electricity consumption [24]. There are also reports of heatwave deaths associated with UHIs [24]. 
Traditional UHI methods were mainly based on temperature data obtained from meteorological stations or vehicle-based surveys. However, remote sensing is a relatively new technique used as a suitable replacement for traditional methods in research on UHIs. Although the climatic data recorded by meteorological stations cover relatively long-term periods, their spatial resolution is low due to the limited number of stations with large geographical distances in between, reducing the accuracy of spatial generalization and thus the reliability of urban micro-climate studies. However, remote sensing techniques have the advantage of acquiring large-scale, high-spatial-resolution data over short temporal scales [25].

Remote sensing has provided a strong foundation for retrieving heat maps and determining the earth's surface radiative energy using large-scale and well-timed automated sensing of energy from the electromagnetic spectrum [26]. These images also have a wide diversity of applications in global research on urban land use analysis [27]. Using the images with appropriate resolutions, it is now possible to retrieve UHIs at different continental and regional scales, produce quantitative data on heterogeneous land surface characteristics, and better understand the relationship between temperature and urban and non-urban environments [28].

Deciding on the choice of thermal data and the type of sensor is a crucial step in spatial modeling because numerous different thermal sensors are now available for the study of urban thermal environments, such as coarse-resolution sensors of the Geodynamics Experimental Ocean Satellite (GEOS) with a spatial resolution of $4 \mathrm{~km}$, the National Oceanic and Atmospheric Administration (NOAA), the Advanced Very-High-Resolution Radiometer (AVHRR), and the Moderate Resolution Imaging Spectroradiometer (MODIS) with a spatial resolution of $1 \mathrm{~km}$ and medium-resolution sensors of the Advanced Spaceborne Thermal Emission and Reflection Radiometer (ASTER) and the Enhanced Thematic Mapper (ETM ${ }^{+}$) with thermal band resolutions of 90 and $60 \mathrm{~m}$, respectively. In the published studies, the land surface temperature was only retrieved from images of different medium-resolution satellites, including Landsat, Terra, and Aqua satellites and the Thematic Mapper (TM), $\mathrm{ETM}^{+}$, ASTER, MODIS, and the Thermal Infrared Sensor (TIRS) sensors.

The main algorithms used for retrieval of land surface temperature are (1) the singlewindow method, (2) the single-channel method, (3) the Surface Energy Balance Algorithm for Land (SEBAL), (4) the Landsat Science Office, and (5) Stephen-Boltzmann [29], of which SEBAL was found to be the most applied algorithm in the selected articles.

Classification techniques were applied to represent the details of LULCs by grouping image pixels into separate classes. There are three main types of classification [30]: (1) unsupervised classification, (2) supervised classification, and (3) object-oriented classification.

(1) Unsupervised classification: Pixels are divided into groups based on their reflective properties. These groups are called clusters. The user specifies the number of clusters and the type of bands for image classification. This type of classification is used when no training data are available.

(2) Supervised classification: The user labels candidate pixels as representatives of each LULC class to train the classification algorithm and perform the classification procedure. There are various supervised algorithms whose selection is a function of the classification purpose, the image properties, and the sample types were taken. The most common supervised algorithms are maximum likelihood and minimum distance. The maximum likelihood algorithm was also the most-applied classification algorithm in the reviewed literature, except for one study that used the K-mean method. This indicates the high accuracy of the classification results using the maximum likelihood algorithm.

(3) Object-oriented classification: This classification method is different from the other two types and is known as multi-resolution segmentation. In this type of classification, homogeneous objects are produced and classified by grouping pixels based on texture, content, and geometric shape. Several bands can be used for object-oriented classification. The user specifies sample points for each LULC after multi-resolution segmentation and 
performs calculations for object classification, allowing the software to classify the objects based on their similarity to the training points.

Supervised and unsupervised classifications were common in the 1970s. However, the object-oriented classification method is a newly developed and increasingly popular technique for image classification [30]. Our results showed that $90 \%$ of the studies used unsupervised and supervised classification methods individually or in combination to produce LULC maps. However, only $10 \%$ of the studies used the object-oriented approach.

In the evaluated studies, error matrices, ground observations, land use maps, and higher-spatial-resolution satellite images were used separately or in combination to evaluate the classification results. Of note is that hybrid methods, such as detailed field surveys and the construction of error matrices, provided more comprehensive assessments. Moreover, the validity of LST maps was commonly estimated using data from ground stations. Table 1 summarizes the spatial modeling articles by purpose and structure.

Table 1. Spatial modeling articles by purpose and structure.

\begin{tabular}{|c|c|c|c|c|c|c|}
\hline $\begin{array}{l}\text { Validation } \\
\text { Methods }\end{array}$ & $\begin{array}{l}\text { Supervised } \\
\text { Algorithm } \\
\text { Methods }\end{array}$ & $\begin{array}{l}\text { Classification } \\
\text { Methods }\end{array}$ & Sensor Name & Satellite & Purpose & Reference \\
\hline Error matrix & MLH & Supervised & $\mathrm{TM}$ & Landsat & LST, land use & [31] \\
\hline $\begin{array}{l}\text { Kappa coefficient, } \\
\text { metrological data }\end{array}$ & MLH & Supervised & ETM+ & Landsat & $\begin{array}{l}\text { LST, UHI, land } \\
\text { use/land cover }\end{array}$ & [32] \\
\hline Metrological data & - & - & TIRS, OLI & Landsat 8 & LST & [33] \\
\hline $\begin{array}{l}\text { Metrological data, } \\
\text { error matrix } \\
\text { Topographic }\end{array}$ & MLH & Supervised & ETM+ & Landsat 7 & $\begin{array}{l}\text { Land use/land } \\
\text { cover, UHI }\end{array}$ & {$[34]$} \\
\hline $\begin{array}{l}\text { maps, land use, } \\
\text { metrological data, } \\
\text { error matrix }\end{array}$ & MLH & Supervised & $\mathrm{TM}, \mathrm{ETM}^{+}$ & Landsat $5,7,8$ & LST, UHI, land use & [35] \\
\hline Metrological data & - & - & TM, OLI - TIRS & Landsat 5,8 & LST & [36] \\
\hline $\begin{array}{c}\text { Ground } \\
\text { observations }\end{array}$ & - & - & $\mathrm{ETM}^{+}$ & Landsat 7 & LST & [37] \\
\hline Metrological data & - & - & OLI - TIRS & Landsat 8 & LST & [38] \\
\hline Metrological data & - & - & OLI, ASTER & Landsat 8, Terra & $\begin{array}{l}\text { LST, Dem, slope, } \\
\text { and aspect maps }\end{array}$ & [39] \\
\hline Metrological data & - & - & - & Landsat 8 & LST & [40] \\
\hline Metrological data & - & - & MODIS & Terra, Aqua & LST & [41] \\
\hline $\begin{array}{l}\text { Metrological data, } \\
\text { IKONOS images }\end{array}$ & - & - & $\mathrm{ETM}^{+}$ & Landsat 7 & LST, UHI & [33] \\
\hline Metrological data & - & - & TM, ETM+ & Landsat 8 & LST & [29] \\
\hline Metrological data & - & - & OLI, TIRS & Landsat 8 & LST & [42] \\
\hline Metrological data & - & - & $\begin{array}{l}\text { TM, } \mathrm{ETM}^{+}, \text {OLI, } \\
\text { TIRS }\end{array}$ & Landsat 8 & LST & [43] \\
\hline Metrological data & - & - & $\mathrm{ETM}^{+}$ & Landsat 7 & LST (UHI) & [44] \\
\hline $\begin{array}{l}\text { Metrological data, } \\
\text { land use/land } \\
\text { cover maps }\end{array}$ & MLH & Supervised & Aster & Terra & $\begin{array}{l}\text { LST, land use/land } \\
\text { cover }\end{array}$ & [45] \\
\hline Metrological data & - & - & $\mathrm{TM}$ & Landsat & LST (UHI) & [46] \\
\hline $\begin{array}{l}\text { Metrological data, } \\
\text { land use/land } \\
\text { cover maps }\end{array}$ & - & - & Aster & Terra & LST(UHI) & [47] \\
\hline Metrological data & - & - & Aster & Terra & LST & [48] \\
\hline $\begin{array}{l}\text { Field surveys, } \\
\text { metrological data }\end{array}$ & MLH, K-Mean & $\begin{array}{c}\text { Supervised and } \\
\text { unsupervised }\end{array}$ & $\mathrm{ETM}^{+}$ & Landsat & $\begin{array}{l}\text { LST (UHI), land } \\
\text { use/land cover }\end{array}$ & [49] \\
\hline Field data & - & - & $\mathrm{ETM}^{+}$ & Landsat 7 & Air pollution map & {$[50]$} \\
\hline Metrological data & - & - & Aster & Terra & LST (UHI) & [51] \\
\hline
\end{tabular}


Table 1. Cont.

\begin{tabular}{|c|c|c|c|c|c|c|}
\hline $\begin{array}{l}\text { Validation } \\
\text { Methods }\end{array}$ & $\begin{array}{l}\text { Supervised } \\
\text { Algorithm } \\
\text { Methods }\end{array}$ & $\begin{array}{l}\text { Classification } \\
\text { Methods }\end{array}$ & Sensor Name & Satellite & Purpose & Reference \\
\hline Metrological data & MLH & Supervised & $\mathrm{TM}, \mathrm{ETM}^{+}$ & Landsat $4,5,7$ & $\begin{array}{l}\text { LST (UHI), land } \\
\text { use/land cover }\end{array}$ & [52] \\
\hline Metrological data & - & - & $\mathrm{TM} \mathrm{ETM}^{+}$ & Landsat 5, 7 & $\begin{array}{l}\text { LST (UHI), land } \\
\text { use/land cover }\end{array}$ & [53] \\
\hline Metrological data & $\begin{array}{l}\text { ISODATA, } \\
\text { MLH }\end{array}$ & $\begin{array}{c}\text { Supervised and } \\
\text { unsupervised }\end{array}$ & $\mathrm{TM}, \mathrm{ETM}^{+}$ & Landsat 7 & $\begin{array}{l}\text { LST (UHI), land } \\
\text { use/land cover }\end{array}$ & {$[54]$} \\
\hline Metrological data & - & $1-$ & OLI, TIRS & Landsat 8 & LST (UHI) & [55] \\
\hline $\begin{array}{l}\text { RMSE, RelRMSE, } \\
\text { MSE, RD }\end{array}$ & MLH & Supervised & $\mathrm{TM} \mathrm{ETM}^{+}$ & Landsat 7 & LST (UHI) & {$[56]$} \\
\hline $\begin{array}{l}\text { Metrological data, } \\
\text { error matrix }\end{array}$ & MLH & Supervised & OLI, TIRS & Landsat 8 & $\begin{array}{l}\text { LST(UHI), land } \\
\text { use/land cover }\end{array}$ & [57] \\
\hline $\begin{array}{l}\text { Metrological data, } \\
\text { error matrix }\end{array}$ & MLH & Supervised & $\mathrm{TM}, \mathrm{ETM}^{+}$ & Landsat 4, 5, 7 & $\begin{array}{l}\text { LST (UHI), land } \\
\text { use/land cover }\end{array}$ & [58] \\
\hline Metrological data & - & Object-oriented & TIRS & Landsat 8 & $\begin{array}{l}\text { LST (UHI), land } \\
\text { use/land cover }\end{array}$ & [59] \\
\hline- & - & - & OLI, TIRS & Landsat 8 & LST & {$[60]$} \\
\hline- & - & - & OLI, TIRS & Landsat 8 & LST & {$[61]$} \\
\hline $\begin{array}{l}\text { Metrological data, } \\
\text { error matrix }\end{array}$ & - & Object-oriented & $\begin{array}{l}\text { OLI, TIRS, } \\
\text { ETM }^{+}\end{array}$ & Landsat 7, 8 & $\begin{array}{l}\text { LST (UHI), land } \\
\text { use/land cover }\end{array}$ & {$[62]$} \\
\hline $\begin{array}{l}\text { Metrological data, } \\
\text { error matrix }\end{array}$ & MLH & Supervised & TM, OLI, TIRS & Landsat 5, 8 & $\begin{array}{l}\text { LST (UHI), land } \\
\text { use/land cover }\end{array}$ & [63] \\
\hline Metrological data & - & - & OLI, TIRS & Landsat 8 & LST (UHI) & {$[64]$} \\
\hline Error matrix & MLH & $\begin{array}{l}\text { Supervised \& } \\
\text { unsupervised }\end{array}$ & $\mathrm{ETM}^{+}$ & Landsat 7 & LST, land cover & {$[65]$} \\
\hline Error matrix & - & Supervised & TM, OLI, ETM ${ }^{+}$ & Landsat 5, 7, 8 & $\begin{array}{l}\text { LST (UHI), land } \\
\text { use/land cover }\end{array}$ & {$[66]$} \\
\hline Error matrix & MLH & Supervised & TM, OLI, ETM ${ }^{+}$ & Landsat 5, 7, 8 & $\begin{array}{l}\text { LST (UHI), land } \\
\text { use/land cover }\end{array}$ & [67] \\
\hline Error matrix & MLH & Supervised & TM, OLI & Landsat $4,5,8$ & $\begin{array}{l}\text { LST (UHI), land } \\
\text { use/land cover }\end{array}$ & [68] \\
\hline $\begin{array}{l}\text { Topographic maps, } \\
\text { metrological data, } \\
\text { error matrix }\end{array}$ & - & - & $\mathrm{ETM}^{+}, \mathrm{TIRS}$ & Landsat 7, 8 & LST (UHI) & [69] \\
\hline $\begin{array}{l}\text { Topographic maps, } \\
\text { metrological data, } \\
\text { error matrix }\end{array}$ & - & - & OLI & Landsat 8 & LST (UHI) & {$[70]$} \\
\hline $\begin{array}{l}\text { Topographic maps, } \\
\text { metrological data, } \\
\text { error matrix }\end{array}$ & MLH & Supervised & $\mathrm{TM}$ & Landsat 4,5 & $\begin{array}{l}\text { LST(UHI), land } \\
\text { use/land cover }\end{array}$ & {$[71]$} \\
\hline $\begin{array}{l}\text { Metrological data, } \\
\text { error matrix }\end{array}$ & MLH & Supervised & - & Landsat 7 & $\begin{array}{l}\text { LST, land use/land } \\
\text { cover }\end{array}$ & {$[72]$} \\
\hline Metrological data & - & - & $\mathrm{ETM}^{+}$ & Landsat 7 & LST & [73] \\
\hline
\end{tabular}

\subsubsection{Statistical Analysis}

Statistics refers to scientific methods used to collect, organize, summarize, classify, analyze, and interpret information [74] in various disciplines, especially in understanding the characteristics of climatic factors. The broad temporal pattern of climate change studies highlights the use of long-term data recorded at ground stations and the adoption of statistical methods that have the potential to analyze long-term data series. According to Figure 6 and Table 2, about $52 \%$ of the selected articles applied statistical analysis to examine the climate change risk of urban development and LULC changes. However, different statistical methods were used depending on the research objectives, such as trend analysis (detection of UHIs or other climatic factors and their temporal variability using station information), time series analysis, and comparison of climatic factors. The primary 
purposes of the articles using comparison and analysis of statistical relationships were to investigate the relationship between LULC changes and UHIs or other climatic factors, comparison of several LST retrieval methods, and analyzing their relationship with land surface changes and identification of the most influential factors affecting climatic variability. In many cases, spatial modeling and statistical analysis were used in combination.

Table 2. Statistical analysis articles by purpose and structure.

\begin{tabular}{|c|c|c|c|}
\hline Meteorological Station & Models & Purpose & Reference \\
\hline Synoptic & Mann-Kendall, regression & Time series analysis & {$[31]$} \\
\hline Synoptic, rain gauge & $\begin{array}{c}\text { Kruskal-Wallis, Kendall's tau, } \\
\text { Mann-Kendall }\end{array}$ & Time series analysis & [75] \\
\hline Synoptic, dry-temperature sensor & Average, geostatistics & $\begin{array}{l}\text { Comparison and analysis of } \\
\text { statistical relationships }\end{array}$ & {$[76]$} \\
\hline- & Regression & $\begin{array}{l}\text { Comparison and analysis of } \\
\text { statistical relationships }\end{array}$ & {$[39]$} \\
\hline- & Local Moran's I statistic & $\begin{array}{l}\text { Comparison and analysis of } \\
\text { statistical relationships }\end{array}$ & [29] \\
\hline- & Local Moran's I statistic & $\begin{array}{l}\text { Comparison and analysis of } \\
\text { statistical relationships }\end{array}$ & [42] \\
\hline- & Mann-Kendall & Trend analysis & [43] \\
\hline Synoptic, climatology & - & $\begin{array}{l}\text { Trend analysis, comparison, and } \\
\text { analysis of statistical relationships }\end{array}$ & {$[77]$} \\
\hline- & Regression & $\begin{array}{l}\text { Comparison and analysis of } \\
\text { statistical relationships }\end{array}$ & {$[44]$} \\
\hline- & Correlation coefficient, regression & $\begin{array}{l}\text { Comparison and analysis of } \\
\text { statistical relationships }\end{array}$ & {$[45]$} \\
\hline- & $\begin{array}{l}\text { Spatial autocorrelation (global } \\
\text { Moran's I statistic), local spatial } \\
\text { autocorrelation (local Moran's I } \\
\text { statistic) }\end{array}$ & $\begin{array}{l}\text { Comparison and analysis of } \\
\text { statistical relationships }\end{array}$ & {$[46]$} \\
\hline- & Kruskal-Wallis, correlation coefficient & $\begin{array}{l}\text { Comparison and analysis of } \\
\text { statistical relationships }\end{array}$ & {$[47]$} \\
\hline Dry-temperature sensor, synoptic & $\begin{array}{l}\text { Average, temperature equivalent } \\
\text { maps }\end{array}$ & $\begin{array}{l}\text { Comparison and analysis of } \\
\text { statistical relationships }\end{array}$ & {$[78]$} \\
\hline- & Correlation coefficient & $\begin{array}{l}\text { Comparison and analysis of } \\
\text { statistical relationships }\end{array}$ & {$[51]$} \\
\hline- & Global Moran's I statistic & $\begin{array}{l}\text { Comparison and analysis of } \\
\text { statistical relationships }\end{array}$ & {$[55]$} \\
\hline Meteorological data recorder & One-way ANOVA & $\begin{array}{l}\text { Comparison and analysis of } \\
\text { statistical relationships }\end{array}$ & {$[79]$} \\
\hline Synoptic & Average & $\begin{array}{l}\text { Comparison and analysis of } \\
\text { statistical relationships }\end{array}$ & {$[80]$} \\
\hline Synoptic & Regression, T-test & $\begin{array}{l}\text { Comparison and analysis of } \\
\text { statistical relationships }\end{array}$ & {$[72]$} \\
\hline- & Regression & $\begin{array}{l}\text { Comparison and analysis of } \\
\text { statistical relationships }\end{array}$ & {$[58]$} \\
\hline Synoptic, climatology & Average & $\begin{array}{l}\text { Comparison and analysis of } \\
\text { statistical relationships }\end{array}$ & {$[81]$} \\
\hline Synoptic & $\begin{array}{l}\text { Regression, kriging interpolation, } \\
\text { autocorrelation (Moran's I statistic), } \\
\text { statistics }\end{array}$ & $\begin{array}{l}\text { Comparison and analysis of } \\
\text { statistical relationships }\end{array}$ & {$[82]$} \\
\hline Synoptic & Mann-Kendall & Time series analysis & {$[83]$} \\
\hline Synoptic & Pearson correlation, regression & $\begin{array}{l}\text { Comparison and analysis of } \\
\text { statistical relationships }\end{array}$ & {$[84]$} \\
\hline- & Regression & $\begin{array}{l}\text { Comparison and analysis of } \\
\text { statistical relationships }\end{array}$ & {$[65]$} \\
\hline Synoptic & Regression & $\begin{array}{l}\text { Comparison and analysis of } \\
\text { statistical relationships }\end{array}$ & {$[66]$} \\
\hline
\end{tabular}


Table 2. Cont.

\begin{tabular}{|c|c|c|c|}
\hline Meteorological Station & Models & Purpose & Reference \\
\hline Synoptic & Regression & $\begin{array}{l}\text { Comparison and analysis of } \\
\text { statistical relationships }\end{array}$ & [85] \\
\hline Synoptic & Mann-Kendall & $\begin{array}{l}\text { Comparison and analysis of } \\
\text { statistical relationships }\end{array}$ & [86] \\
\hline Synoptic & Regression & $\begin{array}{l}\text { Comparison and analysis of } \\
\text { statistical relationships }\end{array}$ & [67] \\
\hline Synoptic & Regression & $\begin{array}{l}\text { Comparison and analysis of } \\
\text { statistical relationships }\end{array}$ & [87] \\
\hline- & Regression & $\begin{array}{l}\text { Comparison and analysis of } \\
\text { statistical relationships }\end{array}$ & [68] \\
\hline Air-pollution-monitoring station & Correlation coefficient & $\begin{array}{l}\text { Comparison and analysis of } \\
\text { statistical relationships }\end{array}$ & [50] \\
\hline Synoptic & - & Time series analysis & [88] \\
\hline- & $\begin{array}{c}\text { Autocorrelation (Moran's I statistic), } \\
\text { statistics }\end{array}$ & $\begin{array}{l}\text { Comparison and analysis of } \\
\text { statistical relationships }\end{array}$ & [36] \\
\hline $\begin{array}{l}\text { Air-pollution-monitoring station, } \\
\text { synoptic, climatology }\end{array}$ & Correlation coefficient & $\begin{array}{l}\text { Comparison and analysis of } \\
\text { statistical relationships }\end{array}$ & {$[64]$} \\
\hline Synoptic, climatology & Mann-Kendall & $\begin{array}{c}\text { Comparison and analysis of } \\
\text { statistical relationships, trend } \\
\text { analysis }\end{array}$ & [89] \\
\hline Synoptic, climatology & - & Trend analysis & [73] \\
\hline- & Regression, GAM, SVM, BRT, RF & $\begin{array}{l}\text { Comparison and analysis of } \\
\text { statistical relationships }\end{array}$ & [70] \\
\hline Synoptic & T test, Von Neumann, autocorrelation & Time series, trend analysis & [90] \\
\hline
\end{tabular}

Meteorological data were also used more frequently for statistical analysis or accurate assessment of UHI modeling results. According to the Iran Meteorological Organization, three meteorological stations record weather data in Iran, including terrestrial, coastal, and high-altitude stations. There are also different terrestrial stations: synoptic stations (complete monitoring equipment), agricultural research stations, and climatology stations. As shown in Table 2 and Figure 7, the selected studies used data from different terrestrial stations. Data from synoptic stations accounted for $59 \%$ of the studies. However, only $8 \%$ of the reviewed literature used data from air-pollution-monitoring stations that belong to the Iranian Department of Environment.

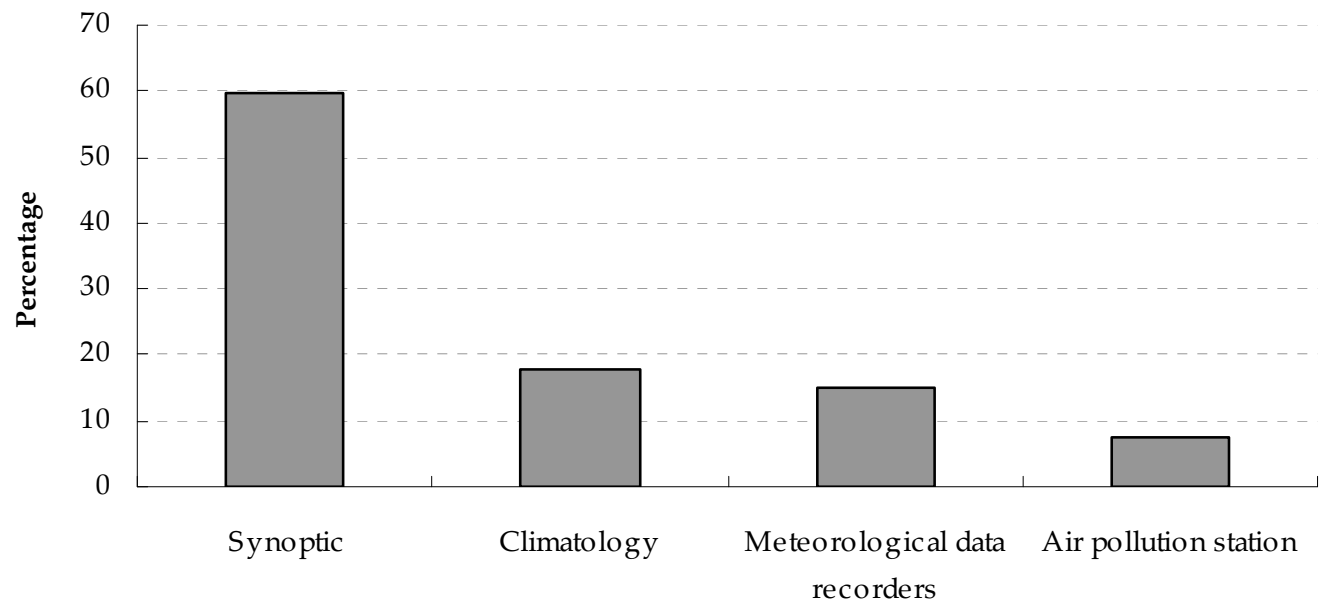

Meteorological data

Figure 7. Meteorological station in the reviewed literature. 


\subsubsection{Numerical Modeling}

Climate models are essential tools for predicting the effects of climate change and understanding the complex relationships between land, atmosphere, and ocean [19,91]. Since the development of initial models known as general atmosphere circulation models, significant improvements have been made in the predictive potency of numerical climate models. The development of computational facilities and advances in the basics of this knowledge (physics and dynamics) have largely improved their predictive clarity and accuracy. These provide good opportunities to explore the earth and atmosphere processes more accurately and realistically and, therefore, enhance weather forecasting from a few weeks to a few days at regional and larger scales. The critical challenge in large urban areas is the simulation of small-scale urban features underused in regional-scale climate models. Recent advances in simulating street and urban-driven air turbulences have introduced a new generation of modeling using effective urban parameters [92,93]. More information about the effect of urbanization on climatic conditions and the effects of LULC on climatic conditions is available in Le Treut et al. [94].

Measurement and analysis of these micro-urban characteristics allow accurate assessment and simulation of the climate of urban areas. Accordingly, several urban canopy designs and related atmospheric models are divided into three general categories. Two categories are single-layer and multi-layer urban canopy designs with simple geometry and are well connected with numerical meteorological models. The third category incorporates the properties of buildings into a variety of computer fluid dynamics (CFD) models to investigate their thermal effects [4]. Of the articles reviewed, only $12 \%$ used different numerical models. One study evaluated the impact of urban growth on regional climate change using factor analysis (FA) and analytical network process (ANP) analysis. Furthermore, seven articles performed a detailed and local-scale investigation of the impacts of urban development on the behavior of climatic variables. Among the seven studies, in two studies, the impact of urban geometry on the intensity of UHIs was investigated using the numerical equation OKE. Four papers applied the ENVI-met model to simulate the behavior of wind velocity, temperature, and UHIs caused by urban geometry, topography, the density and height of buildings, traffic load, width, and direction of passages. Among the seven studies, one study [73] combined spatial modeling, statistical analysis, and the ENVI-met model to assess and reduce the effect of UHIs on urban development at a local scale. Another article predicted the effects of climate change on the design of residential buildings with the Givoni's bioclimatic (GB) chart and the Canadian Earth System Model (CESM) [95]. Meteorological information was most obtained from synoptic stations in these articles, while only two articles used NCEP information. In Table 3, these articles are categorized by purpose and structure.

Table 3. Numerical modeling articles by purpose and structure.

\begin{tabular}{|c|c|c|c|}
\hline Meteorological Station & Models & Purpose & Reference \\
\hline Synoptic & OKE & $\begin{array}{c}\text { Investigating the effect of urban geometry on the } \\
\text { intensity of UHIs }\end{array}$ & [88] \\
\hline Synoptic & ENVI-met & $\begin{array}{c}\text { Simulating the behavior of wind velocity caused by } \\
\text { urban geometry }\end{array}$ & [96] \\
\hline Synoptic & ENVI-met & $\begin{array}{l}\text { Analyzing the effect of urban design on wind speed } \\
\text { and temperature variability }\end{array}$ & [97] \\
\hline NASA/GES, NOAA/NCEP & $\begin{array}{l}\text { Hybrid factor analysis (FA) and } \\
\text { analytical network process (ANP) }\end{array}$ & $\begin{array}{c}\text { Evaluating the effect of urban growth on regional } \\
\text { climate change }\end{array}$ & [98] \\
\hline Synoptic & ENVI-met & $\begin{array}{l}\text { Exploring reconfiguration scenarios of high-density } \\
\text { urban neighborhoods on urban temperature }\end{array}$ & [99] \\
\hline NCEP, IPCC & $\begin{array}{l}\text { Givoni's bioclimatic chart, the } \\
\text { second-generation Canadian Earth } \\
\text { System Model }\end{array}$ & $\begin{array}{l}\text { Projecting the impact of climate change on design } \\
\text { recommendations for residential buildings }\end{array}$ & [95] \\
\hline Synoptic & ENVI-met & $\begin{array}{c}\text { Review and reduce the heat island effect of urban } \\
\text { development }\end{array}$ & [73] \\
\hline- & OKE & $\begin{array}{l}\text { Calculating the urban heat island intensity based on } \\
\text { urban geometry }\end{array}$ & [26] \\
\hline
\end{tabular}




\section{Discussion}

The results yielded in climatic factors, such as temperature, UHIs, precipitation, wind direction, and velocity, agreed with those of other scientists $[6,11,100,101]$. According to previous studies, unplanned changes in LULC have a negative effect on the environment by increasing the LST, evaporation rates, relative humidity, and irregular rainfall, which can affect water quality and the water-energy balance, soil quality, biodiversity, and ecosystem services [102,103].

Moreover, findings of air quality parameters and pollutants were in line with those of Baklanov et al. [5] and Adimalla et al. [104] due to the focus on the impact of urban development on the concentration of contaminants. Increasing numbers of people in developing countries, plus unprecedented rates of urbanization, have had a devastating impact on surrounding land, as well as biotic and abiotic resources [105]. Several researchers contend that this pressure is behind the increasing LULC changes in these regions $[105,106]$. Moreover, as developing countries become more urbanized, air pollution poses serious health risks to urban residents. According to Marshall et al. [107], the population density in urban areas often results in increased traffic congestion and harmful gas emissions, thereby affecting residents' health. So, due to its population size, large extent, and severe air pollution problem, more accurate and detailed prediction is highly needed to be performed in Tehran [108]. According to Frank and Engelke [108], the rise in urban population density will increase transportation demand and air pollution. In addition, rapid population growth in cities leads to changes in LULC by displacing natural resources with urban built-up areas [109-111].

However, the subjects reviewed in this paper, including models, climatic factors, spatio-temporal scales, and the data source, were similar to those of Yan et al. [112]. Studies conducted in Iran were mostly large-scale, a finding in line with past research $[7,8]$. Based on literature reviews, remote sensing in conjunction with GIS technology can provide advanced, powerful synoptic tools to understand better and monitor the spatial, temporal, and spectral characteristics of LULC changes at micro- and macro-scales [113-115]. A trend has emerged to monitor and model spatial data to satisfy the needs of policymakers and planners for precisely and accurately achieving LULC information [116].

We found that $79 \%$ of the national studies used temperature-related factors (i.e., air temperature, LST, and UHI) to explain urban growth and LULC conversion. In accordance with our findings, most of the temperature-related factors are associated with LULC changes caused by widespread and unplanned urbanization, which decreases evapotranspiration and aggravates the soil moisture deficit $[117,118]$. As the earth's surface changes due to temperature changes, the LST is increasingly regarded as an extremely important factor $[119,120]$. In addition, we found that SEBAL is the most-applied algorithm for retrieval of the LST. The SEBAL model has been one of the most widely used over the past 20 years because of its solid physical foundation and ability to automatically correct atmospheric effects on the LST [121,122].

A limited number of studies (5\%) predicted future urban development and LULC changes to investigate their contribution to future climate change, which is similar to the findings of Taha [9] and Fernando et al. [10] but contradicts Baklanov et al. [5] and Garuma [19], because the majority of studies in other parts of the world performed longterm predictions. Data on the location, spatial extent, rate, and driving factors of urban growth have always been problematic in developing countries, making it difficult to implement effective and suitable planning policies. As the dynamic spatio-temporal change process of urban development cannot be prevented, predicting countries' future growth could be a powerful tool to understand the effects of rapid urbanization [123]. During current years, scientists have developed many models that can be used to predict LULC change [123-126]. Dynamic models (e.g., cellular automata and Markov chain) seem to be superior to empirical or statistical models at predicting changes in LULC in the future $[127,128]$. To date, many software packages are available to model future LULC change patterns based on the past year's dataset of climatic parameters and LULC, 
such as the Land Change Modeler (LCM), Cellular Automata and Markov Chain (CAMC), DINAMICA, SLEUTH, CLUE-S, and Modules of Land Use Change Evaluation (MOLUSCE) [109,129].

Despite technical advances in the quality of satellite images, image classification techniques are still the most crucial factor affecting feature extraction accuracy. In a study at the University of Arkansas, high-resolution color aerial images and high-resolution satellite imagery were used to compare various classification methods. In both cases, the object-oriented approach outperformed the other two classification methods because of the simultaneous application of spectral data and contextual information [130]. Classification techniques are applied to represent the details of LULC by grouping image pixels into separate classes. Our results showed that $90 \%$ of the national papers used unsupervised and supervised classification methods individually or in combination to produce LULC maps. Technically, supervised classification is more accurate and reliable than the unsupervised technique, but both are superior to object-oriented classification [30]. The supervised classification techniques include the following models: random forest (RF), radial basis function (RBF), multilayer perception (MLP), decision tree (DT), support vector machine (SVM), spectral angle mapper (SAM), fuzzy adaptive resonance theory-supervised predictive mapping (fuzzy ARTMAP), naive Bayes (NB), Mahalanobis distance (MD), maximum likelihood classifier (MLC), and fuzzy logic [130-132]. Models for unsupervised classification include the affinity propagation (AP) cluster algorithm, fuzzy c-means algorithms, K-means algorithm, and iterative self-organizing data (ISODATA) [133,134].

Our synthesis showed that in many cases, spatial modeling and statistical analysis were used combined with the temporal analysis of LULC. Statistical methods and RS and GIS techniques have been used as an efficient substitute for assessing urban expansion and LULC [135-138].

In terms of data sources, only seven studies used micro-urban parameters as input data of numerical models, which differed from the findings of past studies $[5,11,13,18,19,110]$, showing the wide application of such data in the studies of this field. As mentioned in the methodology section, spatial modeling and statistical analysis were the most widely applied technique in the selected studies. Numerical models were also the least applied method, while the results of some studies (e.g., [12-14,16,17]) showed that micro-scale numerical modeling has been more interested in the relevant literature.

\section{Research Gap and Future Directions}

Studies of the complex interactions between climate, air quality, and megacities represent a relatively new and essential field of research. Many international studies have been initiated during the past decade. In particular, several major projects have been recently realized in Mexico City, European cities, and urban studies and measurement networks in Asia. They quantified feedback mechanisms linking megacity air quality, local and regional climates, and global climate change. They developed improved tools for predicting highimpact weather events and air pollution levels in megacities. While significant advances have been made, new interdisciplinary research studies are needed to increase our current understanding of the interactions between emissions, air quality, and regional and global climates in megacities. These should include studies to address fundamental and applied research; bridge the spatial and temporal scales connecting local emissions, air quality, and weather with climate and global atmospheric chemistry; and, finally, be oriented toward realizing integrated urban services [5].

However, the number of studies conducted in this field is small compared to the rapid development and the increasing number of problems. Early studies dealt with the impacts of LULC conversion on climate change. Current studies have also incorporated urban development at large-scales but lack the effects of micro-scale urban changes on climate change. Therefore, it is crucial to increase awareness in this research field and provide promising directions for future studies to identify, prevent, and minimize the destructive effects of climate change and urban development. Therefore, in proportion 
to the rate of population growth, urban development, various economic-environmental problems, and the need to better ensure the well-being of urban residents, it is necessary to conduct targeted, comprehensive, and appropriate studies. The enormous gap in these studies is the underuse of numerical models that take small changes into account and accurately predict future climate change. Although many coarse-scale studies have been presented in the literature, limited attempts have been made to perform analysis at the neighborhood level. The spatial distribution of case study urban areas was not uniform, so 21 studies were carried out in Tehran City. Hence, it is suggested that national-scale studies be conducted using a combination of statistical, spatial, and numerical models in order to facilitate a more comprehensive understanding of the country's situation. Numerical modeling at the neighborhood level can also lead to a more accurate understanding of future climate change and contribute to the proper design of the urban fabric. Future studies recommend studying these changes in different cities, and if studies are conducted on an urban scale (such as Tehran), the study timescale, data nature, measurement factor, and measurement method should be changed. The most significant gap and rarely addressed issue in the timescale of these studies is the prediction of future urban development and LULC changes and the subsequent climate change in comparison with each other and also in comparison with world research. Therefore, it is suggested that more attention be paid to long-term predictions of these changes in order to provide a thorough basis for planning and managing these changes.

An important consideration in future studies is the accurate measurement of precipitation, wind direction and velocity, relative humidity, air pollutants, and the combination of these factors with temperature, which are less represented in these articles. If a study examines the temperature parameter, the spatial scale, temporal scale, data type, and methodology should be upgraded. Although the data used in these studies were from various sources, there is still a significant gap in using micro-scale urban data, such as the type and height of buildings, urban fabric design, urban streets, and different population compositions, that can help more detailed analysis. The use of high-spatial-resolution sensors is suggested in spatial modeling methods. It is also recommended that various methods be used in retrieving UHIs, in addition to the SEBAL algorithm. The use of the object-oriented method is also recommended in LULC classification. If pixel-based methods, such as supervised classification, were used, it would be helpful to consider the results of other algorithms, such as the neural network and support vector machine.

\section{Conclusions}

This study is the first attempt at conducting a thorough review relating to the strengths and weaknesses of published articles on the effects of urban growth and LULC change on climate change in Iran. Studies conducted in this field are in their infancy and have mostly performed coarse-scale investigations on urban development and climate change. The main results of our national synthesis are divided into the following categories:

Tehran City, with 21 articles, was the most studied case area. Due to its population size, large extent, and severe air pollution problem, more accurate and detailed prediction is highly needed to be performed in Tehran.

Proper spatial distribution of studies and modeling these effects in different urban contexts are also imperative. Identification of these changes and their consequences before urban development is a must to inform land planners and policymakers regarding the effects of their decisions, a consideration that has been neglected in urban development on Iran and, thus, has created numerous environmental problems for urban residents and also in local emissions, air quality with climate, and global atmospheric chemistry.

Our synthesis showed that $12 \%$ use of numerical models, minimal application of microurban parameters, a lack of studies at the urban neighborhood scale, and future prediction of these changes in only $5 \%$ of the articles underscore further use of numerical models at local scales to predict the influence of urban micro-scale parameters on climate change. This would be helpful in the appropriate designation of the urban fabric, the comfort of 
citizens, and the reduction in resource consumption (energy, water) and environmentaleconomic problems. Different methods are needed to make long-term predictions of these changes at urban, regional, and national scales because it leads to a better pre-development planning process.

Due to rapid urbanization and the high levels of air pollution in most metropolitan areas, it is suggested that future research adopt a more diverse combination of data, such as urban parameters with socio-economic-environmental parameters, as well as a broader range of climatic parameters, thus gaining better insights into the changes and their consequences. Air pollution in large urban areas, dispersion of air pollutants and their effects on public health, and global climate changes are also important topics to address in future research at different spatial scales.

Finally, it should be noted that alleviating the effects of urban development, especially its climatic effects, would be possible by increasing effective research in line with world development, which requires purposeful, accurate research based on different and diverse methods.

Supplementary Materials: The following are available online at https:/ /www.mdpi.com/article/10 .3390 / su14010338/s1, Table S1: Reviewed studies on climate change risk of urban growth and land use/land cover conversion.

Author Contributions: Conceptualization, S.E., A.D., A.S. and S.M.M.S.; methodology, S.E. and S.M.M.S.; software, S.E. and S.M.M.S.; validation, S.E., A.D. and A.S.; formal analysis, S.E. and S.M.M.S.; investigation, S.E.; data curation, S.E. and S.M.M.S.; writing-original draft preparation, S.E., A.D. and A.S.; writing-review and editing, S.M.M.S. and M.V.M.; visualization, S.M.M.S. and M.V.M.; supervision, A.D., A.S., S.M.M.S. and M.V.M.; funding acquisition, M.V.M. All authors have read and agreed to the published version of the manuscript.

Funding: This research received no external funding, and the APC was funded by the Department of Forest Engineering, Forest Management Planning and Terrestrial Measurements, Faculty of Silviculture and Forest Engineering, Transilvania University of Brasov.

Institutional Review Board Statement: Not applicable.

Informed Consent Statement: Not applicable.

Data Availability Statement: The data that support the findings of this study are available from the first author upon reasonable request.

Acknowledgments: The authors would like to thank three anonymous reviewers who provided valuable comments on an earlier draft. This work was partially supported by the Department of Forest Engineering, Forest Management Planning and Terrestrial Measurements, Faculty of Silviculture and Forest Engineering, Transilvania University of Brasov.

Conflicts of Interest: The authors declare that they have no conflict of interest.

\section{References}

1. United Nations. 2017. Available online: https:/ /www.un.org/en/ (accessed on 17 December 2020).

2. Chapman, S.; Watson, J.E.; Salazar, A.; Thatcher, M.; McAlpine, C.A. The Impact of Urbanization and Climate Change on Urban Temperatures: A Systematic Review. Landsc. Ecol. 2017, 32, 1921-1935. [CrossRef]

3. Hidalgo, J.; Masson, V.; Baklanov, A.; Pigeon, G.; Gimeno, L. Advances in Urban Climate Modeling. Ann. N. Y. Acad. Sci. 2008, 1146, 354-374. [CrossRef]

4. Wang, J.; Yan, Z.W. Urbanization-Related Warming in Local Temperature Records: A Review. Atmos. Ocean. Sci. Lett. 2016, 9, 129-138. [CrossRef]

5. Baklanov, A.; Molina, L.; Gauss, M. Megacities, Air quality, and Climate. Atmos. Env. 2016, 126, 235-249. [CrossRef]

6. Oke, T.R. Review of Urban Climatology; World Meteorological Organization: Geneva, Switzerland, 1979.

7. Changnon, J.S.A. METROMEX: A Review and Summary; Springer: Berlin/Heidelberg, Germany, 2013.

8. Landsberg, H.E. The Urban Climate; Academic Press: Cambridge, MA, USA, 1981.

9. Taha, H. Urban Climates and Heat Islands: Albedo, Evapotranspiration, and Anthropogenic Heat. Energy Build. 1997, 25, 99-103. [CrossRef] 
10. Fernando, H.J.S.; Lee, S.M.; Anderson, J.; Princevac, M.; Pardyjak, E.; Grossman-Clarke, S. Urban Fluid Mechanics: Air Circulation and Contaminant Dispersion in Cities. Env. Fluid Mech. 2001, 1, 107-164. [CrossRef]

11. Arnfield, A. Two Decades of Urban Climate Research: A Review of Turbulence, Exchanges of Energy and Water, and the Urban Heat Island. Int. Climatol. 2003, 23, 1-26. [CrossRef]

12. Masson, V. Urban Surface Modeling and the Meso-Scale Impact of Cities. Theor. Appl. Climatol. 2006, 84, 35-45. [CrossRef]

13. Grimmond, C.; Blackett, M.; Best, M.; Barlow, J.; Baik, J.; Belcher, S.E.; Bohnenstengel, S.; Calmet, I.; Dandou, A.; Fortuniak, K.; et al. The International Urban Energy Balance Models Comparison Project: First Results from Phase 1. J. Appl. Meteorol. Climatol. 2010, 49, 1268-1292. [CrossRef]

14. Kanda, M. Progress in the Scale Modeling of Urban Climate: Review. Theor. Appl. Climatol. 2006, 84, 23-33. [CrossRef]

15. Kanda, M. Progress in Urban Meteorology: A Review. J. Meteorol. Soc. Jpn. 2007, 85, 363-383. [CrossRef]

16. Roth, M. Review of Urban Climate Research in (Sub)Tropical Regions. Int. J. Climatol. 2007, 27, 1859-1873. [CrossRef]

17. Baklanov, A.; Korsholm, U.; Mahura, A.; Petersen, C.; Gross, A. Enviro-HIRLAM: On-Line Coupled Modelling of Urban Meteorology and Air Pollution. Adv. Sci. Res. 2008, 2, 41-46. [CrossRef]

18. Grimmond, C.; Blackett, M.; Best, M.; Baik, J.; Belcher, S.E.; Beringer, J.; Bohnenstengel, S.; Calmet, I.; Coutts, A.; Dandou, A.; et al. Initial Results from Phase 2 of the International Urban Energy Balance Model Comparison. Int. J. Climatol. 2011, 31, $244-272$. [CrossRef]

19. Garuma, G.F. Review of Urban Surface Parameterizations for Numerical Climate Models. Urban Clim. 2018, $24,830-851$. [CrossRef]

20. Statistics Center of Iran. 2017. Available online: https:/ /www.amar.org.ir/ (accessed on 12 January 2019).

21. Alijani, B. Climate Change and Its Signs in Iran; IRNA: Tehran, Iran, 2020.

22. Nazari, M.; Chaichi, M.R.; Kamel, H.; Grismer, M.; Sadeghi, S.M.M. Evaluation of Estimation Methods for Monthly Reference Evapotranspiration in Arid Climates. Arid Ecosyst. 2020, 10, 329-336. [CrossRef]

23. Oke, T. The Energetic Basis of the Urban Heat Island. Q. J. R. Meteorol. Soc. 1982, 108, 1-24. [CrossRef]

24. Salamanca, F.; Georgescu, M.; Mahalov, A.; Moustaoui, M.; Wang, M.; Svoma, B. Assessing Summertime Urban Air Conditioning Consumption in a Semiarid Environment. Environ. Res. Lett. 2013, 8, 34022. [CrossRef]

25. Alijani, B.; Toulabinejad, M.; Sayadi, F. Calculation of Heat Island Intensity Based on Urban Geometry (Case Study: District of Kucheh Bagh in Tabriz). J. Spat. Anal. Environ. Hazards 2017, 4, 99-112.

26. Ismail, M.H.; Jin Aik, D.H.; Alias, M.A.; Muharam, F.M.; Zaki, P.H. Land Use/Land Cover (LULC) Changes in Cameron Highlands, Malaysia: Explore the Impact of the LULC Changes on Land Surface Temperature (LST) Using Remote Sensing. Clim. Impacts Sustain. Nat. Resour. Manag. 2021, 14, 279-301.

27. Kumar, S.; Jain, K. A Multi-Temporal Landsat Data Analysis for Land-Use/Land-Cover Change in Haridwar Region using Remote Sensing Techniques. Procedia Comput. Sci. 2020, 171, 1184-1193. [CrossRef]

28. Polydoros, A.; Mavrakou, T.; Cartalis, C. Quantifying the Trends in Land Surface Temperature and Surface Urban Heat Island Intensity in Mediterranean Cities in View of Smart Urbanization. Urban Sci. 2018, 2, 16. [CrossRef]

29. Ebrahimi Heravi, B.; Rangzan, K.; Riahi Bakhtiari, H.R.; Taghizadeh, A. Determination of Urban Surface Temperature Using Landsat Images (Case Study: Karaj). J. RS GIS Nat. Resour. 2015, 6, 19-32.

30. Zaidi, S.M.; Akbari, A.; Abu Samah, A.; Kong, N.S.; Gisen, A.; Isabella, J. Landsat-5 Time Series Analysis for Land Use/Land Cover Change Detection Using NDVI and Semi-Supervised Classification Techniques. Pol. J. Environ. Stud. 2017, 26, 2833-2840. [CrossRef]

31. Mazidi, A.; Narangifard, M. The Effect of Urban Development and Land-Use Change on the Climatic Elements of Shiraz and Fasa. Appl. Res. Geogr. Sci. 2016, 16, 131-154.

32. Sasanpour, F.; Ziaeian, P.; Bahadori, M. Investigation of Land Use/Land Cover Relationship and Tehran Urban Heat Island. Geography 2014, 39, 256-270.

33. Aliabadi, K.; Dadashi Roudbari, A. The Role of Geographic Components on the Temperature Dispersion at the Urban Area Using Remote Sensing Techniques Case Study of Mashhad City. Geogr. Plan. Space 2017, 7, 131-142.

34. Maroofnezhad, A. Effect of Urban Land Use in Creation Heat Islands Case Study: Ahwaz. Environ.-Based Territ. Plan. 2011, 4, 65-90.

35. Karimi Firozjaei, M.; Kiavarz Moghaddam, M.; Alavipanah, S.K. Monitoring and Predicting Spatial-Temporal Changes Heat Island in Babol City due to Urban Sprawl and Land-Use Changes. Eng. J. Geospat. Inf. Tech. 2017, 5, 123-151. [CrossRef]

36. Khosravi, Y.; Heidari, M.; Tavakoli, A.; Zamani, A. Analysis of the Relationship between Temporal Changes in Land Surface Temperature and Spatial Pattern of Land-Use Changes (Case Study: Zanjan City). Spat. Plan. 2017, 21, 119-144.

37. Hashemi, M.; Alavi Panah, K.; Dinarvandi, M. Evaluation of Spatial Distribution of Surface Temperature in Urban Environment Using Thermal Remote Sensing. Environ. Sci. 2013, 39, 81-92.

38. Feizizadeh, B.; Didehban, K.; Gholamnia, K. Extraction of Land Surface Temperature (LST) Based on Landsat Satellite Images and Split-Window Algorithm Study Area: Mahabad Catchment. Graph. Data. 2016, 25, 171-181.

39. Valizadeh, K.; Gholamnia, K.; Einali, G.; Mousavi, M. Estimation of Surface Temperature and Extraction of Heat Islands Using Separate Window Algorithm and Multivariate Regression Analysis (Case Study: Zanjan City). Res. Urban Plan. 2018, 8, 35-50. 
40. Samiei, M.; Derakhshan, S.; Rahmani, S.; Hamedi Shahraki, N. Estimation of the Surface Temperature Using Landsat 8 Satellite Images in Firoozabad Urban Area. In Proceedings of the Second National Conference of Hydrology in IRAN, Shahrekord, Iran, 11 July 2017; pp. 1-8.

41. Ahmadi, M.; Dadashiroudbari, A.; Ahmadi, H. Monitoring of the Night-Time Land Surface Temperature in Iran Based on Output of the MODIS. Geogr. Res. 2018, 33, 174-190. [CrossRef]

42. Ebrahimi Heravi, B.; Rangzan, K.; Riahi Bakhtiari, H.R.; Taghizadeh, A. Determining the Most Suitable Method for Extracting Surface Temperature Using Landsat 8 Satellite Images in Karaj Metropolis. Iran. J. Remote Sens. GIS 2016, 8, 59-76.

43. Hashemi Darehbadami, S.; Nouraeisefat, I.; Karami, S.; Nazari, S. Development Trend Analysis of Urban Heat Island Regarding Land Use/Cover Changes Using Time Series of Landsat Images. J. RS GIS Nat. Resour. 2015, 6, 15-28.

44. Shakiba, A.; Firoozabadi, P.; Ashourloo, D.; Namdari, S. Analysis of Relationship between Land Use/Cover and Urban Heat Island, Using $\mathrm{ETM}^{+}$. Remote Sens. GIS 2009, 1, 39-56.

45. Malekpour, P.; Taleai, M. Modeling of the Relationship between Land Use/Cover and Land Surface Temperature Using ASTER Datasets. J. Environ. Stud. 2011, 37, 29-42.

46. Sadeghinia, A.; Alijani, B.; Zeaiean Firouzabadi, P.; Khledi, S. Application of Spatial Autocorrelation Techniques in Analyzing the Heat Island of Tehran. J. Geogr. Sci. 2012, 13, 67-90.

47. Matkan, A.A.; Nohegar, A.; Mirbagheri, B.; Torkchin, N. Assessment Relations of Land Use in Heat Islands Using Time Series ASTER Sensor Data (Case Study: Bandar Abbas City). J. RS GIS Nat. Resour. 2015, 5, 1-14.

48. Akhondzadeh, M.; Serajian, M. Application of Terra-Aster Satellite Images in Display of Heat Islands in Urban Areas. In Proceedings of the Second Conference on Dealing with Natural Disasters, Tehran, Iran, 13-14 February 2007; pp. 1-9.

49. Rangzan, K.; Firoozi, M.; Taghizadeh, A.; Mehdizadeh, R. Investigation and Analysis of Land Use Role in the Formation of Heat Islands Using RS and GIS, Case Study: Ahvaz City. In Proceedings of the First National Seminar in Application of GIS in Economic, Social and Urban Planning, Tehran, Iran, 11 May 2011; pp. 1-12.

50. Nazarian, A.; Ziaeian Firouzabadi, P.; Jangi, A.A. Studying the Role of Geographical Site Urban Morphology on the Air Pollution of Concentration Tehran Area with GIS and Rs. Geogr. Res. Q. 2008, 39, 17-30.

51. Feizizadeh, B.; Blaschke, T. Examining Urban Heat Island Relations to Land Use and Air Pollution: Multiple Endmember Spectral Mixture Analysis for Thermal Remote Sensing. IEEE J. Sel. Top. Appl. Earth Observ. Remote Sens. 2013, 6, 1749-1756. [CrossRef]

52. Amiri, R.; Weng, Q.; Alimohammadi, A.; Alavipanah, S.K. Spatial-Temporal Dynamics of Land Surface Temperature with Fractional Vegetation Cover and Land Use/Cover in the Tabriz Urban Area, Iran. Remote Sens. Environ. 2009, 113, $2606-2617$. [CrossRef]

53. Mousavi Baigi, M.; Ashraf, B.; Farid Hosseini, A.; Miyanaabadi, A. Studying the Heat Island in Mashhad City Using Satellite Images and Fractal Theory. Geogr. Environ. Hazards. 2012, 1, 35-49.

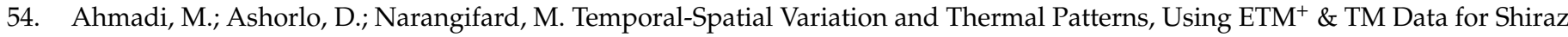
city. Remote Sens. GIS 2013, 4, 55-67.

55. Torkashvand, M.G. Detection of Heat Islands over Arak City based on Spatial Autocorrelation Analysis. Environ.-Based Territ. Plan. 2016, 9, 123-148.

56. Feizizadeh, B.; Blaschke, T.; Nazmfar, H.; Akbari, E. Monitoring Land Surface Temperature Relationship to Land Use/Land Cover from Satellite Imagery in Maraqeh County, Iran. J. Env. Plan. Manag. 2012, 56, 1290-1305. [CrossRef]

57. Pirnazar, M.; Roustaei, S.; Feizizadeh, B.; Raeisi Nafchi, F. Calculating the Earth Surface Temperature and Its Relation to Urban Land Cover Classes by Landsat 8 Data (Case Study: Tehran City). Geogr. Plan. Space Q. J. 2018, 29, 227-240.

58. Amiri, R.; Alimohammadi, A.; Alavipanah, S.K. The Study of Spatiotemporal Variability of Temperature with Land Use/Cover in the Tabriz Urban Area Using Landsat TM and ETM ${ }^{+}$Thermal and Reflective Data. J. Environ. Stud. 2007, 33, 107-120.

59. Hasanloo, M.; Mashroteh, H. Investigation Relation of Land Use/Land Cover and Thermal Islands in Kerman Using Landsat-8 images. In Proceedings of the First Conference on Spatial Information Technology Engineering, Tehran, Iran, 21 December 2015; pp. 1-7.

60. Khosroshahi, S.; Abdollah Abadi, S.; Omrani, K. Evaluating the spatial distribution of land surface temperatures in an urban environment by using thermal remote sensing (Case Study: Tabriz). In Proceedings of the First National Conference on Geography, Urban Planning, and Sustainable Development, Tehran, Iran, 5 November 2012; pp. 1-9.

61. Maleki, M.; Mohammadzadeh, K.; Fathi, M. Evaluation of Spatial Distribution of Surface Temperature in Urban Environment Using Thermal Remote Sensing (Case Study: Marand City). In Proceedings of the 2nd International Congress of Earth Sciences and Urban Development, Tabriz, Iran, 12 May 2016; pp. 1-9.

62. Asghari Saraskanroud, S.; Emami, H. Monitoring the Earth Surface Temperature and Relationship Land Use with Surface Temperature Using of OLI and TIRS Image. J. Geogr. Sci. 2019, 19, 195-215.

63. Hosseini, Z.; Zarang, N.; Hajiloo, M.; Dadashi, M.; Tayba, A. Investigating the Relationship between Land Surface Temperature (LST) Changes and Vegetation with Landsat Images (Case Study: Isfahan). In Proceedings of the First National Conference on Application Advanced Models of Spatial Analysis, Remote Sensing and GIS in Landscaping, Yazd, Iran, 24 February 2015; pp. 1-13.

64. Arvin, A. An Investigation of the Relationship between Urban Heat Island and Air Pollution in the City of Isfahan. Geogr. Env. Hazards 2018, 7, 115-129. 
65. Asgarian, A.; Amiri, B.J.; Sakieh, Y. Assessing the Effect of Green Cover Spatial Patterns on Urban Land Surface Temperature using Landscape Metrics Approach. Urban Ecosyst. 2015, 18, 209-222. [CrossRef]

66. Afrakhteh, R.; Asgarian, A.; Sakieh, Y.; Soffianian, A. Evaluating the Strategy of an Integrated Urban-Rural Planning System and Analyzing Its Effects on Land Surface Temperature in a Rapidly Developing Region. Habitat Int. 2016, 56, 147-156. [CrossRef]

67. Emadodin, I.; Taravat, A.; Rajaei, M.; Emadodin, I.; Taravat, A.; Rajaei, M. Effects of Urban Sprawl on Local Climate: A Case Study, North-Central Iran. Urban Clim. 2016, 17, 230-247. [CrossRef]

68. Naserikia, M.; Asadi Shamsabadi, E.; Rafieian, M.; Leal Filho, W. The Urban Heat Island in an Urban Context: A Case Study of Mashhad, Iran. Int. J. Environ. Res. Public Health 2019, 16, 313. [CrossRef]

69. Shirani-Bidabadi, N.; Nasrabadi, T.; Faryadi, S.; Larijani, A.; Shadman Roodposhti, M. Evaluating the Spatial Distribution and the Intensity of Urban Heat Island using Remote Sensing, Case Study of Isfahan City in Iran. Sustain. Cities Soc. 2019, 45, 686-692. [CrossRef]

70. Shafizadeh-Moghadam, H.; Weng, Q.; Liu, H.; Valavi, R. Modeling the Spatial Variation of Urban Land Surface Temperature Concerning Environmental and Anthropogenic Factors: A Case Study of Tehran, Iran. GIS Sci. Remote Sens. 2020, 57, $483-496$. [CrossRef]

71. Bokaie, M.; Zarkesh, M.K.; Arasteh, P.D.; Hosseini, A. Assessment of Urban Heat Island based on the Relationship between Land Surface Temperature and Land Use/ Land Cover in Tehran. Sustain. Cities Soc. 2016, 23, 94-104. [CrossRef]

72. Dashtakian, K.; Dehghani, M.A. Land Surface Temperature Analysis of the Desert Area with Vegetation and Urban Development using RS and GIS, Case Study: Yazd-Ashekezar Area. Pajouhesh Sazandegi 2008, 20, 169-179.

73. Sodoudi, S.; Shahmohamadi, P.; Vollack, K.; Cubasch, U.; Che-Ani, A.I. Mitigating the Urban Heat Island Effect in Megacity Tehran. Adv. Meteorol. 2014, 2014, 547974. [CrossRef]

74. Nikokar, M. Statistics and Its Application in Management (1). In Expansion of Basic Sciences; Gostaresh Olum Payeh Press: Tehran, Iran, 2019.

75. Rahimi, J.; Bazrafshan, J.; Rahimi, A. Study of the Variations of Precipitation Days under Urban Microclimate in the City of Tehran. Phys. Geogr. Res. Q. 2011, 77, 93-108.

76. Maleki, S.; Shojaeian, A.; Farahmand, G. Assessment of Temporal-Spatial Variability of Heat Islands in Relation to Urban Uses-Case Study: Urmia City. Q. J. Geogr. Inf. 2018, 27, 183-197.

77. Ranjbar Saadatabadi, A.; Ali Akbari Beydokhti, A.A.; Sadeghi Hosseini, S.A. Effects of Urban Heat Island and Urbanization on Weather and Local Climate of Tehran Greater Area (Based on Mehrabad and Varamin Observations). J. Environ. Stud. 2006, 32, 59-68.

78. Ramezani, B.; Dokhat Mohammad, S.M. The Recognition of Urban Heat Island in Rasht City. Res. Urban Plan. 2010, 1, 49-64.

79. Yousefi, Y.; Kardel, F.; Rodeh, H.; Mohtasbi Khalatbari, M. Investigation of Heat Island Phenomenon and Its Effect on Day-to-Day Variability of Summer Temperature in Babol City. Nat. Geogr. Res. 2017, 49, 345-354.

80. Akbari Beidakhti, A.; Ranjbar Saadatabadi, A. Studying the Climatic Impact of the Heat Islands in Tehran. In Proceedings of the Third Regional and the First National Conference on Climate Change, Isfahan, Iran, 17-21 April 2003; pp. 1-12.

81. Mousavi-Baygi, M.; Ashraf, B.; Mianabadi, A. The Investigation of Tehran's Heat Island by using the Surface Ozone and Temperature Data. Int. J. Appl. Environ. Sci. 2010, 5, 189-200.

82. Karami, M.; Dadashi Roudbari, A.; Asadi, M. Investigating the Spatial Variation of Heat Islands of Tehran. Int. J. Sci. Res. Publ. 2016, 6, 2250-3153.

83. Alijani, B.; Moayedfar, S.; Sabaeimehr, M. Investigation of Climatic Changes of Yazd City in Relation to Urban and Regional Development. Res. Urban Plan. 2011, 1, 41-58.

84. Roshan, R.; Zanganeh, S.; Saurí, D.; Borna, R. Urban Sprawl and Climatic Changes in Tehran. Iran. J. Environ. Health Sci. Eng. 2010, 1, 7-15.

85. Sarvari, H. A Survey of the Relationship between Urbanization and Climate Change for Major Cities in Iran. Arab. J. Geosci. 2019, 12, 131. [CrossRef]

86. Fanni, Z.; Hosayni, Z.; Afsharmanesh, H.; Nezammahalleh, M.; Rastegar, A. The Effects of Urban Environment on Climate Changes, Case study: Tehran, Iran. Q. J. Tethys 2013, 1, 138-147.

87. Bidokhti, A.; Shariepour, Z.; Sehatkashai, S. Some Resilient Aspects of Urban Areas to Air Pollution and Climate Change, Case Study: Tehran, Iran. Sci. Iran. 2016, 23, 1994-2004.

88. Shokri Koochak, S.; Behnia, A.K. The Effect of the Heat Island Phenomenon on the Local Climate Change in Ahwaz Metropolis. J. Irrig. Sci. Eng. 2011, 34, 35-43.

89. Talebi Kenari, H.; Nikpour, A.; Yousefi, Y. The Impact of Urban Growth on Temperature Variability in Babolsar. Res. Earth Sci. 2018, 9, 21-34.

90. Ataei, H.; Fanaie, R. The Survey of Series Temperature Changes Trend at the City of Shiraz with Urban Development Planning. Res. Urban Plan. 2014, 4, 57-76.

91. Moura, A.D.; Hastenrath, S. Climate Prediction for Brazil's Nordeste: Performance of Empirical and Numerical Modeling Methods. J. Clim. 2004, 17, 2667-2672. [CrossRef]

92. Ching, J.K.S. A Perspective on Urban Canopy Layer Modeling for the Weather, Climate, and Air Quality Applications. Urban Clim. 2013, 3, 13-39. [CrossRef]

93. Barlow, J.F. Progress in Observing and Modeling the Urban Boundary Layer. Urban Clim. 2014, 10, 216-240. [CrossRef] 
94. Le Treut, H.; Somerville, R.; Cubasch, U.; Ding, Y.; Mauritzen, C.; Mokssit, A.; Peterson, T.; Prather, M. Historical Overview of climate change [chapter 1]. In Climate Change 2007: The Physical Science Basis; Solomon, S., Qin, D., Manning, M., Chen, Z., Marquis, M., Averyt, K.B., Tignor, M., Miller, H.L., Eds.; Contribution of Working Group I to the Fourth Assessment Report of the Intergovernmental Panel on Climate Change; Cambridge University Press: Cambridge, UK; New York, NY, USA, 2007; pp. 95-127.

95. Roshan, G.; Oji, R.; Attia, S. Projecting the Impact of Climate Change on Design Recommendations for Residential Buildings in Iran. Build. Environ. 2019, 155, 283-297. [CrossRef]

96. Delfanazari, S.; Saligheh, M.; Akbari, M. Changes in Wind Fields Affected by Urban Development, Case Study: Saadat Abad Neighborhood of Tehran. Res. Earth Sci. 2017, 8, 1-14.

97. Ramyar, R.; Ramyar, A.; Kialashaki, Y.; Bryant, M.; Ramyar, H. Exploring Reconfiguration Scenarios of High-Density Urban Neighborhoods on Urban Temperature-The Case of Tehran (Iran). Urban For. Urban Green. 2019, 44, 126398. [CrossRef]

98. Mansouri Daneshvar, M.R.; Rabbani, G.; Shirvani, S. Assessment of Urban Sprawl Effects on Regional Climate Change Using a Hybrid Model of Factor Analysis and Analytical Network Process in the Mashhad City, Iran. Environ. Syst. Res. 2019, 8, 23-40. [CrossRef]

99. Ramyar, R.; Zarghami, E.; Bryant, M. Spatio-Temporal Planning of Urban Neighborhoods in the Context of Global Climate Change: Lessons for Urban form Design in Tehran, Iran. Sustain. Cities Soc. 2019, 51, 101554. [CrossRef]

100. Oke, T.R. Canyon Geometry and the Nocturnal Urban Heat Island: Comparison of Scale Model and Field Observations. J. Climatol. 1981, 1, 237-254. [CrossRef]

101. Abd El-Hamid, H.T.; Caiyong, W.; Hafiz, M.A.; Mustafa, E.K. Effects of Land Use/Land Cover and Climatic Change on the Ecosystem of North Ningxia, China. Arab. J. Geosci. 2020, 13, 1099. [CrossRef]

102. Kafy, A.A.; Faisal, A.A.; Sikdar, S.; Hasan, M.; Rahman, M.; Khan, M.H.; Islam, R. Impact of LULC Changes on LST in Rajshahi District of Bangladesh: A Remote Sensing Approach. J. Geogr. Stud. 2020, 3, 11-23. [CrossRef]

103. Kafy, A.A.; Naim, M.N.H.; Subramanyam, G.; Ahmed, N.U.; Al Rakib, A.; Kona, M.A.; Sattar, G.S. Cellular Automata Approach in Dynamic Modelling of Land Cover Changes using RapidEye Images in Dhaka, Bangladesh. Environ. Chall. 2021, 4, 100084. [CrossRef]

104. Adimalla, N.; Chen, J.; Qian, H. Spatial Characteristics of Heavy Metal Contamination and Potential Human Health Risk Assessment of Urban Soils: A Case Study from an Urban Region of South India. Ecotoxicol. Environ. Saf. 2020, $194,110406$. [CrossRef]

105. Hassan, M.M.; Nazem, M.N.I. Examination of Land Use/Land Cover Changes, Urban Growth Dynamics, and Environmental Sustainability in Chittagong City, Bangladesh. Environ. Dev. Sustain. 2016, 18, 697-716. [CrossRef]

106. McCarthy, M.P.; Best, M.J.; Betts, R.A. Climate Change in Cities due to Global Warming and Urban Effects. Geophys. Res. Lett. 2010, 37, L09705. [CrossRef]

107. Marshall, J.D.; McKone, T.E.; Deakin, E.; Nazaroff, W.W. Inhalation of Motor Vehicle Emissions: Effects of Urban Population and Land Area. Atmos. Environ. 2005, 39, 283-295. [CrossRef]

108. Heshmatol Vaezin, S.M.; Moftakhar Juybari, M.; Daei, A.; Avatefi Hemmat, M.; Shirvany, A.; Tallis, M.J.; Hirabayashi, S.; Moeinaddini, M.; Hamidian, A.H.; Sadeghi, S.M.M.; et al. The Effectiveness of Urban Trees in Reducing Airborne Particulate Matter by Dry Deposition in Tehran, Iran. Environ. Monit. Assess. 2021, 193, 842. [CrossRef] [PubMed]

109. Esfandeh, S.; Danehkar, A.; Salmanmahiny, A. Simulation and Prediction of Urban Growth Pattern Until 2050 Using SLEUTH-3R Model (Case Study: Coastal Area of Parsian City). Environ. Sci. 2021, 47, 53-72.

110. Dewan, A.M.; Yamaguchi, Y. Using Remote Sensing and GIS to Detect and Monitor Land Use and Land Cover Change in Dhaka Metropolitan of Bangladesh during 1960-2005. Environ. Monit. Assess. 2009, 150, 237-249. [CrossRef] [PubMed]

111. Nilufar, F. Urban Morphology of Dhaka City: Spatial Dynamics of Growing City and the Urban Core. In Proceedings of the International Seminar Proceedings on the Celebration of 400 Years of the Capital Dhaka, Asiatic Society, Dhaka, Bangladesh, 17-19 February 2010; pp. 1-8.

112. Yan, Z.; Wang, J.; Xia, J.; Feng, J. Review of Recent Studies of the Climatic Effects of Urbanization in China. Adv. Clim. Change Res. 2016, 7, 154-168. [CrossRef]

113. Weng, Q. A Remote Sensing-GIS Evaluation of Urban Expansion and Its Impact on Surface Temperature in the Zhujiang Delta, China. Int. J. Remote Sens. 2001, 22, 1999-2014.

114. Taubenbock, H.; Wiesner, M.; Felbier, A.; Marconcini, M.; Dech, T.E. New Dimensions of Urban Landscapes: The Spatio-Temporal Evolution from a Polynuclei Area to a Mega-Region based on Remote Sensing Data. Appl. Geogr. 2014, 47, 137-153. [CrossRef]

115. Bose, A.; Chowdhury, I.R. Monitoring and Modeling of Spatio-Temporal Urban Expansion and Land-Use/Land-Cover Change using Markov Chain Model: A Case Study in Siliguri Metropolitan Area, West Bengal, India. Model. Earth Syst. Environ. 2020, 6, 2235-2249. [CrossRef]

116. Akbar, T.A.; Hassan, Q.K.; Ishaq, S.; Batool, M.; Butt, H.J.; Jabbar, H. Investigative Spatial Distribution and Modelling of Existing and Future Urban Land Changes and Its Impact on Urbanization and Economy. Remote Sens. 2019, 11, 105. [CrossRef]

117. Fitria, R.; Kim, D.; Baik, J.; Choi, M. Impact of Biophysical Mechanisms on Urban Heat Island Associated with Climate Variation and Urban Morphology. Sci. Rep. 2019, 9, 19503. [CrossRef] [PubMed]

118. Wang, R.; Hou, H.; Murayama, Y.; Derdouri, A. Spatiotemporal Analysis of Land Use/Cover Patterns and their Relationship with Land Surface Temperature in Nanjing, China. Remote Sens. 2020, 12, 440. [CrossRef] 
119. Kamran, K.V.; Pirnazar, M.; Bansouleh, V.F. Land Surface Temperature Retrieval from Landsat 8 TIRS: Comparison Between Split Window Algorithm and SEBAL Method. In Proceedings of the Third International Conference on Remote Sensing and Geoinformation of the Environment, Paphos, Cyprus, 16-19 March 2015; pp. 9535-9553.

120. Karger, D.N.; Conrad, O.; Böhner, J.; Kawohl, T.; Kreft, H.; Soria-Auza, R.W.; Kessler, M. Climatologies at High Resolution for the Earth's Land Surface Areas. Sci. Data 2017, 4, 120. [CrossRef] [PubMed]

121. Wang, X.; Kang, Q.; Chen, X.; Fu, Q.; Wang, P. A Temperature-Domain SEBAL Model Based on a Wind Speed-Independent Theoretical Trapezoidal Space between Fractional Vegetation Coverage and Land Surface Temperature. IEEE Geosci. Remote Sens. Lett. 2020, 18, 756-760. [CrossRef]

122. Sultana, N.; Rahman, H.; Sharifee, M.N.H.; Faisal, B.R.; Ahmed, M.T. Study on the Effects of Landcover Changes on Surface Albedo and Surface Temperature in Bangladesh Using Remote Sensing and GIS. Int. J. Environ. Geoinformatics 2019, 6, $277-287$. [CrossRef]

123. Yagoub, M.M.; Al Bizreh, A.A. Prediction of Land Cover Change using Markov and Cellular Automata Models: Case of Al-Ain, UAE, 1992-2030. J. Indian Soc. Remote Sens. 2014, 42, 665-671. [CrossRef]

124. Wang, S.W.; Munkhnasan, L.; Lee, W.K. Land Use and Land Cover Change Detection and Prediction in Bhutan's High Altitude City of Thimphu, Using Cellular Automata and Markov Chain. Environ. Chall. 2021, 2, 100017. [CrossRef]

125. Munthali, M.G.; Mustak, S.; Adeola, A.; Botai, J.; Singh, S.K.; Davis, N. Modelling Land Use and Land Cover Dynamics of Dedza District of Malawi using Hybrid Cellular Automata and Markov Model. Remote Sens. Applic. Soc. Environ. 2020, $17,100276$. [CrossRef]

126. Girma, R.; Fürst, C.; Moges, A. Land Use Land Cover Change Modeling by Integrating Artificial-Neural-Network with Cellular Automata-Markov Chain Model in Gidabo River Basin, Main Ethiopian Rift. Environ. Chall. 2021, 6, 100419. [CrossRef]

127. Guan, D.; Li, H.; Inohae, T.; Su, W.; Nagaie, T.; Hokao, K. Modeling Urban Land Use Change by the Integration of Cellular Automaton and Markov Model. Ecol. Model. 2011, 222, 3761-3772. [CrossRef]

128. Rendana, M.; Rahim, S.A.; Idris, W.M.R.; Lihan, T.; Rahman, Z.A. CA-Markov for Predicting Land Use Changes in Tropical Catchment Area: A Case Study in Cameron Highland, Malaysia. J. Appl. Sci. 2015, 15, 689-695. [CrossRef]

129. Mas, J.F.; Kolb, M.; Paegelow, M.; Olmedo, M.T.C.; Houet, T. Inductive Pattern-Based Land Use/Cover Change Models: A Comparison of Four Software Packages. Environ. Model. Softw. 2014, 51, 94-111. [CrossRef]

130. Najafi, A. Techniques for Classifying Images in Remote Sensing; GIRS: Tehran, Iran, 2016.

131. Ma, L.; Liu, Y.; Zhang, X.; Ye, Y.; Yin, G.; Johnson, B.A. Deep Learning in Remote Sensing Applications: A Meta-Analysis and Review. ISPRS J. Photogramm. Remote Sens. 2019, 152, 166-177. [CrossRef]

132. Shih, H.C.; Stow, D.A.; Tsai, Y.H. Guidance on and Comparison of Machine Learning Classifiers for Landsat-based Land Cover and Land Use Mapping. Int. J. Remote Sens. 2019, 40, 1248-1274. [CrossRef]

133. Talukdar, S.; Singha, P.; Mahato, S.; Pal, S.; Liou, Y.A.; Rahman, A. Land-Use Land-Cover Classification by Machine Learning Classifiers for Satellite Observations-A Review. Remote Sens. 2020, 12, 1135. [CrossRef]

134. Maxwell, A.E.; Warner, T.A.; Fang, F. Implementation of Machine-Learning Classification in Remote Sensing: An Applied Review. Int. J. Remote Sens. 2018, 39, 2784-2817. [CrossRef]

135. Somvanshi, S.S.; Bhalla, O.; Kunwar, P.; Singh, M.; Singh, P. Monitoring Spatial LULC Changes and Its Growth Prediction based on Statistical Models and Earth Observation Datasets of Gautam Budh Nagar, Uttar Pradesh, India. Environ. Dev. Sustain. 2020, 22, 1073-1091. [CrossRef]

136. Mondal, M.S.; Sharma, N.; Garg, P.; Kappas, M. Statistical Independence Test and Validation of CA Markov Land Use Land Cover (LULC) Prediction Results. Egypt. J. Remote Sens. Space Sci. 2016, 19, 259-272. [CrossRef]

137. Tian, X.; Wenbin, W.; Qingbo, Z.; Wenxia, T.; Verburg, P.; Peng, Y.; Liming, Y. Modeling the Spatio-Temporal Changes in Land Uses and Its Impacts on Ecosystem Services in Northeast China Over 2000-2050. J. Geogr. Sci. 2018, 28, 1611-1625.

138. Sobhani, P.; Esmaeilzadeh, H.; Barghjelveh, S.; Sadeghi, S.M.M.; Marcu, M.V. Habitat Integrity in Protected Areas Threatened by LULC Changes and Fragmentation: A Case Study in Tehran Province, Iran. Land 2022, 11, 6. [CrossRef] 